\title{
Diurnal evolution of total column and surface atmospheric ammonia in the megacity of Paris, France, during an intense springtime pollution episode
}

\author{
Rebecca D. Kutzner ${ }^{1}$, Juan Cuesta ${ }^{1}$, Pascale Chelin ${ }^{1}$, Jean-Eudes Petit ${ }^{2,3}$, Mokhtar Ray $^{1}$, Xavier Landsheere ${ }^{1}$, \\ Benoît Tournadre $^{1, a}$, Jean-Charles Dupont ${ }^{4}$, Amandine Rosso ${ }^{5}$, Frank Hase ${ }^{6}$, Johannes Orphal ${ }^{6}$, and \\ Matthias Beekmann ${ }^{1}$ \\ ${ }^{1}$ Laboratoire Interuniversitaire des Systèmes Atmosphériques (LISA), UMR CNRS 7583, Université Paris-Est Créteil, \\ Université de Paris, Institut Pierre-Simon Laplace (IPSL), Créteil, France \\ ${ }^{2}$ Laboratoire des Sciences du Climat et de l'Environnement, UMR 8212, \\ CEA/Orme des Merisiers, 91191 Gif-sur-Yvette, France \\ ${ }^{3}$ INERIS, Parc Technologique ALATA, 60750 Verneuil-en-Halatte, France \\ ${ }^{4}$ Institut Pierre-Simon Laplace, École Polytechnique, UVSQ, Université Paris-Saclay, 91128 Palaiseau, France \\ ${ }^{5}$ Airparif, Agence de surveillance de la qualité de l'air, Paris, France \\ ${ }^{6}$ Institut für Meteorologie und Klimaforschung (IMK), Karlsruher Institut für Technologie (KIT), Karlsruhe, Germany \\ ${ }^{a}$ new affiliation: Centre Observation, Impacts, Energy - Mines ParisTech, Sophia Antipolis CEDEX, France
}

Correspondence: Rebecca D. Kutzner (rebecca.kutzner@lisa.u-pec.fr) and Pascale Chelin (pascale.chelin@lisa.u-pec.fr)

Received: 27 July 2020 - Discussion started: 8 December 2020

Revised: 8 July 2021 - Accepted: 9 July 2021 - Published: 12 August 2021

\begin{abstract}
Ammonia $\left(\mathrm{NH}_{3}\right)$ is a key precursor for the formation of atmospheric secondary inorganic particles, such as ammonium nitrate and sulfate. Although the chemical processes associated with the gas-to-particle conversion are well known, atmospheric concentrations of gaseous ammonia are still scarcely characterized. However, this information is critical, especially for processes concerning the equilibrium between ammonia and ammonium nitrate, due to the semivolatile character of the latter. This study presents an analysis of the diurnal cycle of atmospheric ammonia during a pollution event over the Paris megacity region in spring 2012 (5 d in late March 2012). Our objective is to analyze the link between the diurnal evolution of surface $\mathrm{NH}_{3}$ concentrations and its integrated column abundance, meteorological variables and relevant chemical species involved in gas-particle partitioning. For this, we implement an original approach based on the combined use of surface and total column ammonia measurements. These last ones are derived from ground-based remote sensing measurements performed by the Observations of the Atmosphere by Solar Infrared Spectroscopy (OASIS) Fourier transform infrared ob-
\end{abstract}

servatory at an urban site over the southeastern suburbs of the Paris megacity. This analysis considers the following meteorological variables and processes relevant to the ammonia pollution event: temperature, relative humidity, wind speed and direction, and the atmospheric boundary layer height (as indicator of vertical dilution during its diurnal development). Moreover, we study the partitioning between ammonia and ammonium particles from concomitant measurements of total particulate matter $(\mathrm{PM})$ and ammonium $\left(\mathrm{NH}_{4}^{+}\right)$concentrations at the surface. We identify the origin of the pollution event as local emissions at the beginning of the analyzed period and advection of pollution from Benelux and western Germany by the end. Our results show a clearly different diurnal behavior of atmospheric ammonia concentrations at the surface and those vertically integrated over the total atmospheric column. Surface concentrations remain relatively stable during the day, while total column abundances show a minimum value in the morning and rise steadily to reach a relative maximum in the late afternoon during each day of the spring pollution event. These differences are mainly explained by vertical mixing within the boundary layer, pro- 
vided that this last one is considered well mixed and therefore homogeneous in ammonia concentrations. This is suggested by ground-based measurements of vertical profiles of aerosol backscatter, used as tracer of the vertical distribution of pollutants in the atmospheric boundary layer. Indeed, the afternoon enhancement of ammonia clearly seen by OASIS for the whole atmospheric column is barely depicted by surface concentrations, as the surface concentrations are strongly affected by vertical dilution within the rising boundary layer. Moreover, the concomitant occurrence of a decrease in ammonium particle concentrations and an increase in gaseous ammonia abundance suggests the volatilization of particles for forming ammonia. Furthermore, surface observations may also suggest nighttime formation of ammonium particles from gas-to-particle conversion, for relative humidity levels higher than the deliquescence point of ammonium nitrate.

\section{Introduction}

Ammonia $\left(\mathrm{NH}_{3}\right)$ is a harmful air pollutant that directly affects human health and also contributes to intense smog events through the neutralization of sulfuric and nitric acids for forming secondary aerosols such as ammonium sulfate $\left(\left(\mathrm{NH}_{4}\right)_{2} \mathrm{SO}_{4}\right)$ and nitrate $\left(\mathrm{NH}_{4} \mathrm{NO}_{3}\right)$ (Behera et al., 2013; Seinfeld and Pandis, 2016; Elster et al., 2018). These particles can be transported over long distances, contribute to the degradation of air quality and impact different ecosystems. Through conversion into different forms of reactive nitrogen, further impacts of ammonia and ammonium particles are directly or indirectly linked to acidic precipitation, acidification, eutrophication and loss of biodiversity (e.g., Sutton et al., 2011, 2013; Krupa, 2003). Depending on atmospheric temperature $(T)$, relative humidity $(\mathrm{RH})$ and the $\mathrm{pH}$ of the particles, volatilization of ammonium nitrate particles may form gaseous ammonia (e.g., Seinfeld and Pandis, 2016; Weber et al., 2016; Guo et al., 2018).

The main source of $\mathrm{NH}_{3}$ in Europe is the agricultural sector, with an average of $93 \%$ of total ammonia emission estimated for 2018 (Pinterits et al., 2020). It is emitted by volatilization from fertilizer storage, livestock, and manure and mineral nitrogen fertilizers applied to crops as a function of temperature, humidity, and $\mathrm{pH}$ of atmosphere and soil as well as wind speed (e.g., Sommer et al., 2004, Behera et al., 2013). Other emissions are associated with traffic and industry. In France, the dominant source of $\mathrm{NH}_{3}$ is also attributed to the agricultural sector, with contributions between $94 \%$ and $98 \%$, among which $50 \%$ is due to nitrogen-based fertilizers as well as emissions from livestock (Génermont et al., 2018; Ramanantenasoa et al., 2018). In many regions of Africa, Inner Mongolia, southern Siberia and South America, fires are another anthropogenic source of $\mathrm{NH}_{3}$ (Behera et al., 2013). Natural sources are related to biological mechanisms in soils, plants and the soil-plant interaction, as described in detail by Behera et al. (2013). At the global scale, ammonia emissions are mainly attributed to agriculture, biomass burning and the energy sector, accounting in 2005 for $80.6 \%$, $11.0 \%$ and $8.3 \%$, respectively (Behera et al., 2013).

The European Union (EU) addressed ammonia emission in the National Emission Ceilings Directive 2001/81/EC (NECD). Serrano et al. (2019) recently reviewed reduction efforts of nitrogen levels between 2001 and 2011, finding a significant impact of ammonia emitted from agriculture on ecosystems. Exceedances of ammonia emissions compared to ceilings set for 2010 are still occurring (NECD reporting status 2018). New reduction goals for the period of 2020 to 2029 and a second period after 2030 are set for each European country in Directive (EU) 2016/2284.

Pollution events in urban areas directly impact human health and greatly reduce visibility (e.g., Molina and Molina, 2004). This recurrently occurs during springtime over the Paris megacity (12.2 million inhabitants including suburbs) and other European megacities often associated with emissions from agricultural activities in the areas surrounding the agglomerations (e.g., Petit et al., 2015). Other pollution events in these areas are also linked to local or regional emissions of nitrogen oxides and sulfur dioxide from road traffic and industry (Behera and Sharma, 2010). Accurate and long-term measurements of atmospheric pollutants, such as ammonia, and meteorological conditions are crucial in order to better understand the origin and the evolution of these pollution events. In the Paris region, springtime is a very propitious period for particulate matter pollution episodes, essentially dominated by secondary inorganic aerosols, such as ammonium nitrate and sulfate (Sciare et al., 2011; Petit et al., 2015). Concomitantly, ammonia concentrations have been found to be exceptionally high, as reported by surface in situ measurements (Petit et al., 2015; Petetin et al., 2016) and remote sensing from the ground and satellite (Tournadre et al., 2020; Viatte et al., 2020). Indeed, that period of the year is characterized by fertilizer spreading, which can dramatically enhance $\mathrm{NH}_{3}$ emissions (Ramanantenasoa et al., 2018).

Different techniques are used to measure concentrations of $\mathrm{NH}_{3}$ in the atmosphere. Difficulties to measure ammonia by in situ techniques are associated with its "sticky" nature, inducing its accumulation in inlets and sampling tubes. In order to reduce these artifacts, different techniques are often implemented, such as the use of polyethylene or Teflon tubes (instead of steel or silicosteel) and halocarbon wax coating, while keeping the length of the tubes to a minimum possible and a heating system for reducing relative humidity that may also lead to losses of $\mathrm{NH}_{3}$ (Yokelson et al., 2003; Whitehead et al., 2008).

Remote sensing of ammonia is an innovative alternative to in situ techniques, which offers a significant enhancement of spatial coverage. Satellite approaches are currently based on hyperspectral thermal infrared measurements from 
the Cross-track Infrared Sounder (CrIS; Shephard and CadyPereira, 2015) and the infrared atmospheric sounding interferometer (IASI; Clerbaux et al., 2009), respectively, aboard the United States Suomi National Polar-orbiting Partnership (SNPP) and the European MetOp (Meteorological Operational) satellites. Both platforms are pointing nadir in polar sun-synchronous orbits, with overpasses around 09:30 and 21:30 LT (local time) for IASI and 13:30 and 01:30 LT for CrIS (Shephard and Cady-Pereira, 2015; Dammers et al., 2017). Therefore, they both offer global coverage twice a day, providing particularly valuables measurements over remote regions lacking ground-based instruments such as in the tropics. Remote sensing of ammonia can also be performed using hyperspectral measurements from a groundbased Fourier transform infrared (FTIR) spectrometer, like OASIS (Observations of the Atmosphere by Solar Infrared Spectroscopy; Chelin et al., 2014) mid-resolution observatory in Créteil (France). Remote sensing from satellite and ground-based platforms provides vertically integrated amounts of ammonia over the atmospheric column for cloudfree conditions. The combined use of remote sensing and in situ measurements offers an interesting framework for analyzing ammonia variability both at the surface and integrated over the atmospheric column, as already done for greenhouse gases (Zhou et al., 2018). FTIR ground-based measurements can provide highly valuable information on the diurnal evolution of atmospheric species for a particular geographical location, as shown here for ammonia in the Paris suburbs. Although numerous FTIR ground-based stations currently exist, such as those of the Network for the Detection of Atmospheric Composition Change (NDACC; De Mazière et al., 2018), only a few of them document the diurnal evolution of atmospheric constituents.

This paper presents a detailed analysis of the diurnal evolution of ammonia as observed in total columns from groundbased remote sensing and at the surface from an in situ analyzer in Paris, France, during a major pollution event in late March 2012. We characterize the diurnal variation of ammonia, analyzing both the link with the formation and volatilization of ammonium particles and vertical dilution in the atmospheric boundary layer. Spring 2012 was one of the most polluted periods since 2007 , with a succession of persistent pollution events (Petit et al., 2015, 2017). We use total column ammonia concentrations derived from the OASIS observatory in the southeastern Paris suburbs (Créteil) and surface observations in the southwestern Paris suburbs (Palaiseau) to characterize the diurnal evolution of ammonia between 26 and 30 March 2012. To the authors' knowledge, this is the first analysis of the diurnal evolution of ammonia from both total column and surface measurements, in close relation with particle-phase measurements.

Section 2 provides information concerning the instruments from the OASIS and SIRTA (Site Instrumental de Recherche par Télédétection Atmosphérique) sites, as well as other datasets (see Sect. 2.1, 2.4 and 2.5) used for this study. We also provide a brief description of the new retrieval of ammonia from OASIS (Tournadre et al., 2020). In the third section, we present and discuss the analysis of these datasets. First, we describe the regional conditions of the Paris pollution event in late March 2012 using meteorological analysis, a chemistry-transport model and satellite data (Sect. 3.1). Then, we analyze the diurnal evolution of surface and total columns of ammonia and particulate matter as well as meteorological variables over the Paris region (Sect. 3.2 to 3.4). Following that, we analyze the complementarity of surface and total column measurements of ammonia using groundbased backscatter lidar (LIght Detection And Ranging) measurements, as a proxy for the vertical distribution of pollutants within the atmospheric boundary layer (Sect. 3.5). Section 4 provides conclusions of this study.

\section{Datasets}

\subsection{Description of ground-based sites and platforms}

An original aspect of this work is the analysis of the diurnal evolution of total column observations of ammonia derived from OASIS. This remote sensing observatory is located in Créteil (OASIS; $48.79^{\circ} \mathrm{N}, 2.44^{\circ} \mathrm{E} ; 56 \mathrm{~m}$ a.s.1., above sea level), in the southeastern suburbs of Paris, on the rooftop of the Université Paris-Est Créteil (UPEC; Chelin et al., 2014). It is an urban site mainly affected by background levels of pollution (Fig. 1).

Measurements from other sites over the Paris region are also used in the current study (Fig. 1). Meteorological and detailed atmospheric composition data at the surface level are measured at the "Site Instrumental de Recherche par Télédétection Atmosphérique" supersite near Palaiseau (SIRTA; $48.72^{\circ} \mathrm{N}, 2.20^{\circ} \mathrm{E}$; http://sirta.ipsl.fr, last access: 29 January 2019), located about $19 \mathrm{~km}$ southwest from OASIS and southwest of Paris, which is often used for monitoring background air quality conditions in the Paris region (Haeffelin et al., 2005). We use radiosounding measurements of temperature, pressure and humidity profiles from the Trappes station that is about $31 \mathrm{~km}$ west of Créteil $(15 \mathrm{~km}$ away from the SIRTA supersite) and operated by Météo-France. Additional surface measurements of $\mathrm{PM}_{2.5}$ and $\mathrm{PM}_{10}$ (particle matter with aerodynamic diameters, respectively, less than 2.5 and $10 \mu \mathrm{m}$ ) are provided by the Airparif network dedicated to monitoring air quality in the Paris region (https: //www.airparif.asso.fr/, last access: 17 January 2019) from the stations of Vitry-sur-Seine, Bobigny and Gennevilliers. In the paper, time series of measurements are presented in terms of hourly median values, except when stated otherwise. 


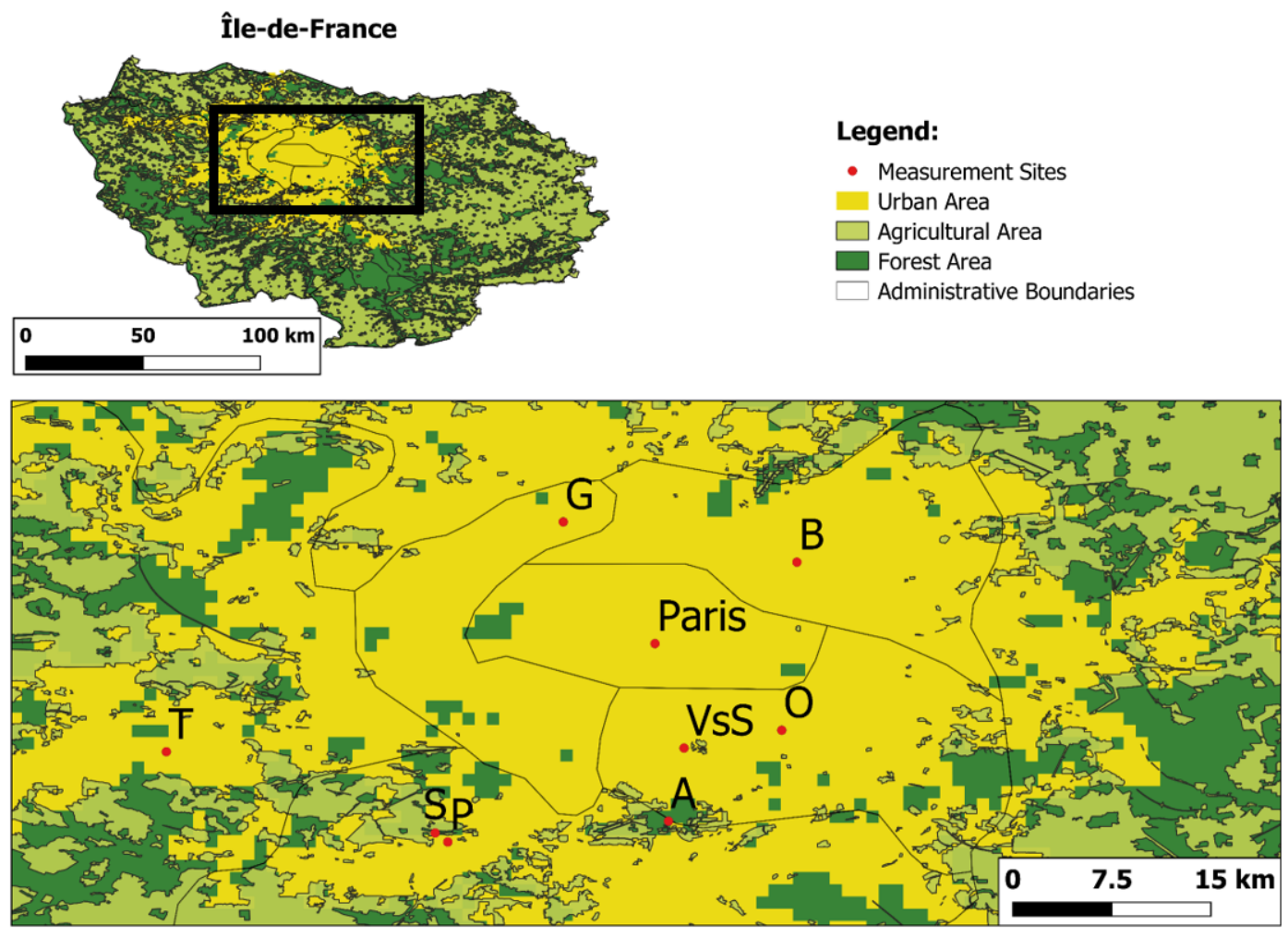

Figure 1. Outline of the Paris region and a zoomed-in view of the relevant sites (A - Airport Orly, B - Bobigny, G - Gennevilliers, O - OASIS, P - Palaiseau, S - SIRTA, T - Trappes, VsS - Vitry-sur-Seine) using shapefiles provided by data.gouv.fr (https://www.data.gouv.fr/fr/datasets/ espaces-agricoles-de-la-region-ile-de-france-inscrits-sur-la-cdgt-du-sdrif-arrete-en-2012-idf/\#discussion-5cc30bdb8b4c4166219c058e, last access: 30 April 2019) and processed with QGIS 3.6.

\subsection{Observations of total column ammonia derived from OASIS}

Since 2009, the OASIS observatory regularly records high spectral measurements of solar radiation absorbed and scattered by atmospheric constituents, under clear-sky conditions (Chelin et al., 2014). It uses a medium-spectral-resolution Fourier transform spectrometer manufactured by Bruker Optics (the Vertex 80 model) with a spectral resolution of $0.06 \mathrm{~cm}^{-1}$ (corresponding to a maximum optical path difference of $12 \mathrm{~cm}$ ). OASIS is routinely used for monitoring air pollutants, such as tropospheric ozone $\left(\mathrm{O}_{3}\right)$ and carbon monoxide (CO), with good accuracy and high sensitivity to near-surface concentrations (Viatte et al., 2011). This system is particularly suited for air quality monitoring in megacities, given its compactness and moderate cost, and it can play a key role in validating current (e.g., IASI) and future satellite observations (e.g., Infrared Atmospheric Sounder Interferometer Next Generation - IASI-NG - and the infrared sounder aboard the Meteosat Third Generation mission MTG/IRS).

The observatory is covered by an automatized cupola (Sirius 3.5 "School Model" observatory, $3.25 \mathrm{~m}$ high and $3.5 \mathrm{~m}$ in diameter), in which the aperture rotates to track the so- lar position. The altitude-azimutal solar tracker of OASIS uses bare gold-coated mirrors (A547N model from Bruker Optics). Infrared solar radiation spectra are recorded by a DTGS (deuterated triglycine sulfate) detector using a potassium bromide $(\mathrm{KBr})$ beam splitter to cover the large spectral region from 700 to $11000 \mathrm{~cm}^{-1}(0.9-14.3 \mu \mathrm{m})$ with no optical filter. The acquisition system is set to average over 30 scans at maximum spectral resolution in order to increase the signal-to-noise ratio of the measurements. This averaging procedure results in an effective temporal resolution of $10 \mathrm{~min}$, that allows for measuring the diurnal variability of relatively short-lifetime species such as $\mathrm{NH}_{3}$. Absolute calibration of spectra measured by OASIS is done every month with a reference internal source of radiation.

Ammonia concentrations integrated over the total atmospheric column are retrieved with the PROFFIT 9.6 code developed by the Karlsruhe Institute of Technology (Germany; Hase et al., 2004), adapted for the medium spectral resolution. As detailed by Tournadre et al. (2020), two spectral microwindows within the $\nu_{2}$ vibrational band of $\mathrm{NH}_{3}$ are used: $926.3-933.9$ and $962.5-970 \mathrm{~cm}^{-1}$. The main interfering species in this spectral range are water vapor $\left(\mathrm{H}_{2} \mathrm{O}\right)$, carbon dioxide and $\mathrm{O}_{3}$, whose abundances are taken from the Whole Atmosphere Community Climate Model (WACCM 


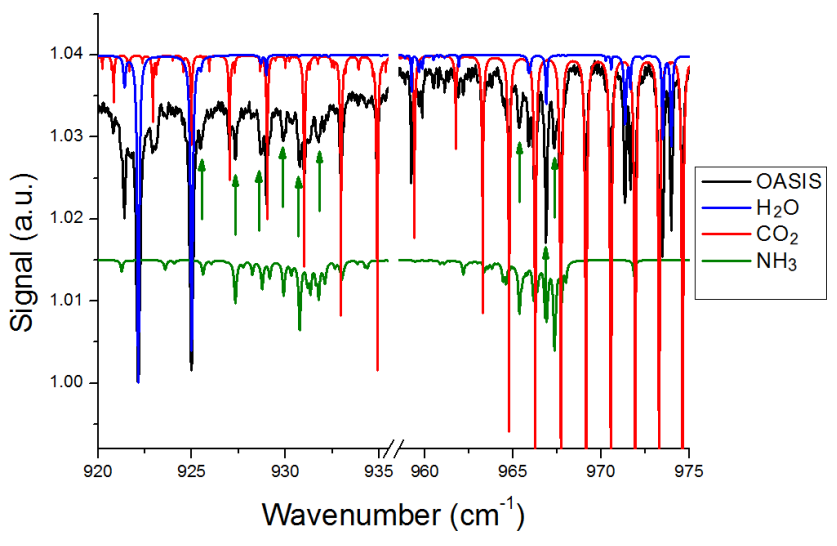

Figure 2. OASIS FTIR atmospheric spectrum recorded with the Bruker Vertex 80 at Créteil on 21 March 2012 in the two microwindows (before and after the spectral gap), showing the strong ammonia absorbing lines (pointed out by the green arrows) around $932 \mathrm{~cm}^{-1}$ (origin of the $\mathrm{NH}_{3} \nu_{2}$ band) with individual contributions of the main interfering species represented from the atlas of Meier et al. (2004). All spectra are plotted using arbitrary unit (a.u.) on the $y$ axis.

version 6: Chang et al., 2008) and jointly adjusted with that of $\mathrm{NH}_{3}$. We also use climatological concentrations for minor interfering gases (i.e., nitric acid, $\mathrm{HNO}_{3}$; sulfur hexafluoride, $\mathrm{SF}_{6}$; ethane, $\mathrm{C}_{2} \mathrm{H}_{4}$; and chlorofluorocarbons - e.g., CFC-12) that may essentially impact the baseline of the spectra. The spectral signatures of absorption of infrared radiation by ammonia are clearly seen in individual spectra measured by OASIS, such as those recorded during a pollution event in March 2012 (as compared to the atlas from Meier et al., 2004; see Fig. 2). Atmospheric columns of ammonia derived from the 9-year database of OASIS range from $0.0005 \times$ $10^{16}$ to $9 \times 10^{16}$ molec. $\mathrm{cm}^{-2}$ (molecules per square centimeter), and their retrieval error is estimated to be $20 \%-35 \%$ (Tournadre et al., 2020), dominated by the systematic errors that are the combination of uncertainties in the spectroscopic parameters of ammonia and the interfering species (the dominating term), radiometric noise, instrumental parameters, and forward model uncertainties. The magnitudes of these errors are comparable to those estimated by Dammers et al. (2015) for a high-resolution ground-based station at Bremen (Germany). OASIS retrievals of $\mathrm{NH}_{3}$ total columns show a good agreement with co-located observations derived from IASI (the ANNI-NH3-v2.2R version; Van Damme et al., 2017): a linear correlation coefficient of $\sim 0.8$ and a small mean difference of $\sim 0.08 \times 10^{16}$ molec. $\mathrm{cm}^{-2}$, with OASIS-derived concentrations slightly larger (Tournadre et al., 2020). This last aspect could be associated with an enhanced sensitivity to larger concentrations of $\mathrm{NH}_{3}$ near the surface for OASIS as compared to the satellite retrieval which is most sensitive to higher atmospheric layers.

\subsection{Surface in situ observations of ammonia and aerosol composition}

In the present analysis, we use in situ gaseous ammonia measurements at surface level carried out with an AiRRmonia instrument (Mechatronics Instruments, the Netherlands) at the SIRTA observatory (Haeffelin et al., 2005). The principle of this instrument, described in Cowen et al. (2004), is essentially based on conductimetric detection of ammonia that is first absorbed via a gas-permeable membrane and dissolved in water (i.e., in the form of ammonium ions, forming acidic solution). Several intercomparison exercises have shown that this procedure provides more accurate $\mathrm{NH}_{3}$ measurements (Norman et al., 2009; von Bobrutzki et al., 2010). The AiRRmonia was regularly calibrated with 0 and 500 ppb ammonium solution.

Concomitant measurements of the major chemical composition of submicron aerosols were performed with an aerosol chemical speciation monitor (ACSM; Aerodyne Research Inc., Billerica, MA, USA; Ng et al., 2011), providing concentrations of particulate organic matter $(\mathrm{OM})$, nitrate $\left(\mathrm{NO}_{3}^{-}\right)$, sulfate $\left(\mathrm{SO}_{4}^{2-}\right)$, ammonium $\left(\mathrm{NH}_{4}^{+}\right)$and chloride $\left(\mathrm{Cl}^{-}\right)$, every $30 \mathrm{~min}$. Submicron particles are sampled at $3 \mathrm{~L} \mathrm{~min}^{-1}$, subsampled at $0.85 \mathrm{~L} \mathrm{~min}^{-1}$ and focused through an aerodynamic lens for $\mathrm{PM}_{1}$ (particle matter with aerodynamic diameter smaller than $1 \mu \mathrm{m})$. Non-refractory particles are then flash-vaporized on a $600^{\circ} \mathrm{C}$ heated plate, fragmented by electronic impact at $70 \mathrm{keV}$, and eventually separated and detected by a quadrupole. Calibrations were performed by injecting known concentrations of ammonium nitrate and ammonium sulfate particles with an aerodynamic diameter of $300 \mathrm{~nm}$. Details on the operational conditions of the AiRRmonia and the ACSM instruments at SIRTA are provided by Petit et al. (2015).

As observed by Petit et al. (2015), we expect the daily evolution of ammonia over the Paris region to be closely linked to the gas-to-particle conversion between ammonia (gas) and ammonium nitrate particles. This is a reversible conversion for which the equilibrium is closely linked to the abundance of precursors $\left(\mathrm{NH}_{3}\right.$ and $\left.\mathrm{HNO}_{3}\right)$ and meteorological conditions, such as temperature and relative humidity (Seinfeld and Pandis, 2016). The conditions needed for volatilization of $\mathrm{NH}_{3}$ from $\mathrm{NH}_{4} \mathrm{NO}_{3}$ are given by the relationship of relative humidity and deliquescence relative humidity (DRH), which depends on temperature, whereby volatilization is favored when RH is much lower than DRH. In order to estimate the balance between DRH and RH, we consider the following equation, as suggested by Seinfeld and Pandis (2016):

$$
\begin{aligned}
\operatorname{DRH}(T) & =\operatorname{DRH}(298) \exp \left\{\frac { \Delta H _ { \mathrm { S } } } { R } \left[A\left(\frac{1}{T}-\frac{1}{298}\right)\right.\right. \\
& \left.\left.-B \ln \frac{T}{298}-C(T-298)\right]\right\},
\end{aligned}
$$


where $\operatorname{DRH}(298)$ is the deliquescence relative humidity of $\mathrm{NH}_{4} \mathrm{NO}_{3}$ at $298 \mathrm{~K}$, which corresponds to $61.8 \% . \Delta H_{\mathrm{S}}$ is the enthalpy of solution for $\mathrm{NH}_{4} \mathrm{NO}_{3}$ at $298 \mathrm{~K}$ which is $25.69 \mathrm{~kJ} \mathrm{~mol}^{-1}, R$ is the universal gas constant and $T$ is the temperature in kelvin. $A, B$ and $C$ are factors for the solubility of common aerosol salts in water as a function of temperature provided by Seinfeld and Pandis (2016) (i.e., 4.3, $-3.6 \times 10^{-2}$ and $7.9 \times 10^{-5}$, respectively). Moreover, partitioning between ammonia and ammonium nitrate is also influenced by the $\mathrm{pH}$ of the ambient particles (e.g., Weber et al., 2016; Guo et al., 2018). When pH drops below an approximate critical value of 3 (slightly higher in warm and slightly lower in cold seasons), the $\mathrm{NH}_{3}$ reduction leads to evaporation of $\mathrm{NH}_{4} \mathrm{NO}_{3}$, while this is not expected to happen for moderately acidic to neutral conditions (Guo et al., 2018). In addition, it is worth noting that in the present study we use the above expression and the currently available data for a qualitative interpretation of diurnal variations of ammonia and ammonium. However, additional dedicated measurements throughout the atmospheric column are needed in order to perform a quantitative analysis (see more details in the conclusion section).

\subsection{Regional conditions from satellite data and models}

For characterizing the pollution event during March 2012, we use a suite of satellite and model datasets concerning both the pollutant distributions at regional and continental scales and meteorological conditions. Aerosol optical depth (AOD) data derived from satellite and groundbased measurements are used for analyzing the spatial and temporal evolution of total particle abundance integrated over the atmospheric column. The horizontal distribution of AOD over western Europe is described using MODIS (Moderate Resolution Imaging Spectroradiometer; Remer et al., 2005) data aboard the Terra (MOD04L2) satellite with overpasses at 10:30 LT (from the NASA Worldview website https://worldview.earthdata.nasa.gov/, last access; 27 February 2019; Levy and Hsu, 2015). The MODIS images have a horizontal resolution of $3 \mathrm{~km}$ at nadir.

The horizontal distribution of air pollutants at the European scale is studied with CHIMERE chemistry-transport model simulations of $\mathrm{PM}_{2.5}$ provided by the ESMERALDA (EtudeS Multi RégionALes De l'Atmosphère; Cortinovis et al., 2006) project (http://www.esmeralda-web.fr/accueil/ index.php, last access: 28 February 2019). The version 2008b of CHIMERE is run hourly and averaged at a daily timescale, with a horizontal resolution of $15 \mathrm{~km} \times 15 \mathrm{~km}$ and nine vertical levels between $20 \mathrm{~m}$ to $5 \mathrm{~km}$. Meteorological inputs for CHIMERE come from MM5 simulations (Dudhia, 1993), using Final (FNL) analysis data from National Centers for Environmental Prediction (NCEP) as boundary conditions. Chemical reactions are simulated using the MELCHIOR2 mechanisms scheme and the ISORROPIA model (Nenes et al., 1998). This last one has been used to produce tables that are inserted in the CHIMERE model for calculating the thermodynamic equilibrium of the species. Ammonia, nitrate and sulfate are simulated in aqueous, gaseous and particulate phases in the model.

Meteorological conditions are analyzed from in situ measurements and numerical model simulations. We use sealevel pressure, wind and potential temperature fields from the ERA-Interim (ERAI; Simmons et al., 2007) reanalysis of the European Centre for Medium-Range Weather Forecasts (ECMWF) that are provided by the Institut PierreSimon Laplace Mésocentre (https://mesocentre.ipsl.fr, last access: 6 March 2019). These simulations have a $0.75 \times 0.75^{\circ}$ horizontal resolution and 37 pressure levels.

\subsection{Local conditions in the Paris region from ground-based measurements}

Meteorological conditions at the surface over the Paris region are analyzed by in situ measurements of wind speed and direction performed at the SIRTA site (Haeffelin et al., 2005). Local temperature and relative humidity were measured at Créteil with a LOG 110-EXF sensor, with an accuracy in temperature of $\pm 0.5^{\circ} \mathrm{C}$ and in relative humidity of $\pm 3 \%$.

Vertical profiles of temperature and relative humidity from the surface up to $25 \mathrm{~km}$ of altitude and with about $10 \mathrm{~m}$ vertical resolution are measured by radiosoundings launched around noon and midnight at the Trappes site (southwest suburbs of Paris).

The diurnal evolution of particle pollution over the Paris region is studied in terms of surface measurements of $\mathrm{PM}_{2.5}$ and $\mathrm{PM}_{10}$ from several Airparif sites and AOD measured by ground-based sun photometers (version 3 of level 2.0 data) at the Paris and SIRTA sites from AERONET (AErosol RObotic NETwork; Holben et al., 2001, https://aeronet.gsfc. nasa.gov/, last access: 9 June 2019). We use the distinction between AOD from a fine (e.g., smoke or smog) and coarse (e.g., sea-salt or dust) modes at $500 \mathrm{~nm}$, derived from the wavelength dependence of the AOD (O'Neill et al., 2003; Giles et al., 2019). Errors in AOD data correspond to approximately 0.02 (Giles et al., 2019).

Additionally, we use ground-based lidar measurements from the SIRTA site for describing the vertical distribution of particles over the Paris region, which is used as an indicator of the vertical distribution of air pollutants and the vertical structure of the atmospheric boundary layer. This is done with vertical profiles of attenuated backscatter profiles, measured by an elastic backscatter lidar (the Leosphere ALS model) at $355 \mathrm{~nm}$. The mixing boundary layer height is visually identified as the lowest marked discontinuity of the lidar profiles during daytime hours (from 06:00 to 18:00 UTC). 


\section{Results}

We focus our study on the diurnal evolution of ammonia during a major pollution event over the Paris region occurring at the end of March 2012. It corresponds to the period with highest concentrations of ammonia on the multiyear time series (2009-2017) of OASIS measurements, which is probably linked to the springtime spreading of mineral fertilizer in the Paris region and the surrounding regions (Ramanantenasoa et al., 2018; Tournadre et al., 2020). It is the most polluted spring season between 2007 and 2015 (Petit et al., 2017).

\subsection{Meteorological and atmospheric conditions over western Europe}

During late March 2012, the prevailing atmospheric conditions over western Europe are driven by an anticyclonic highpressure system centered over Great Britain and the North Sea $\left(55^{\circ} \mathrm{N}, 0^{\circ} \mathrm{E}\right)$ on 26 March and moving westwards in the following days (see Fig. 3a, d and g). Following the anticyclonic circulation associated with this system, northeasterly winds blow from the Benelux region (Belgium, the Netherlands and Luxembourg) to northern France. As expected for an anticyclonic period, relatively low wind speeds occur at its core, located over central Europe (from southern France to eastern Germany), which are accompanied by high insulation and low cloudiness (not shown). According to MODIS satellite observations (Fig. 3b, e and $\mathrm{h}$ ) and CHIMERE simulations (Fig. 3c, f and i), an aerosol plume with moderate AOD (0.2 to 0.3$)$ and moderately large concentrations of $\mathrm{PM}_{2.5}$ at the surface (20 to $30 \mu \mathrm{g} \mathrm{m}^{-3}$ ) is formed on 26 March over Benelux and extends across the English Channel. Meanwhile, aerosol baseline levels are observed over northern France (AOD 0.1 and $10-15 \mu \mathrm{g} \mathrm{m}^{-3}$ for surface $\mathrm{PM}_{2.5}$ ). After $27 \mathrm{March}$, the aerosol plume reaches northern France and southern England. On 28 March, a clear enhancement of the aerosol load over Benelux and northern France is observed both in terms of AOD (up to 0.4) and modeled surface $\mathrm{PM}_{2.5}$ concentrations (up to $50 \mu \mathrm{g} \mathrm{m}^{-3}$ ). These high aerosol loads over northern France remain until 30 March (not shown). Both the horizontal extent of the aerosol plume and wind directions suggest that these highly polluted air masses originate over Benelux as well as western Germany and are transported southwestwards, clearly reaching the Paris region after 28 March (also remarked for this pollution event by Fortems-Cheiney et al., 2016).

\subsection{Geographical distribution of particle matter over the Paris region}

Over the Paris region, particle concentrations at the surface are moderately high during $26-27$ March $\left(\mathrm{PM}_{2.5}\right.$ concentrations up to $40 \mathrm{\mu g} \mathrm{m}^{-3}$; see surface measurements of PM levels from several stations of the Paris region in Fig. 4). As polluted air masses are advected from Benelux and western Germany during 28-29 March, $\mathrm{PM}_{2.5}$ levels are clearly enhanced (up to $80 \mu \mathrm{g} \mathrm{m}^{-3}$ ), as also seen in daily averaged simulations. Figure 4 also shows the largest peaks of surface $\mathrm{PM}_{2.5}$ concentrations occurring every day during the morning and secondary high values in the late evening.

Very similar temporal evolution patterns of surface particle concentrations are observed over the whole Paris region and during the entire period (26-30 March), both in absolute and relative terms. Figure 4 illustrates this horizontally homogeneous distribution of surface PM as the chosen stations are located at the southeastern, southwestern, northeastern and northwestern suburbs of Paris (Fig. 1). The same peaks and troughs of surface PM are seen for all these locations. Particularly, we also remark that $\mathrm{PM}_{1}$ at SIRTA also shows the same temporal evolution as other stations in the Paris region but with levels roughly $\sim 30 \%$ below those of $\mathrm{PM}_{2.5}$ during 26-28 March and similar concentrations afterwards (for both $\mathrm{PM}_{1}$ and $\mathrm{PM}_{2.5}$ ). The $30 \%$ difference between $\mathrm{PM}_{1}$ and $\mathrm{PM}_{2.5}$ observed in the present case could be linked with aging (and/or long-range transport) which has been remarked for measurements in 2015 by Petit et al. (2017). In the Paris region, $\mathrm{PM}_{1}$ generally represents $90 \%$ of $\mathrm{PM}_{2.5}$ (Petit et al., 2017), particularly when $\mathrm{PM}_{1}$ is larger than $20 \mu \mathrm{g} \mathrm{m}^{-3}$ (although for lower levels, $\mathrm{PM}_{1}$ may represent around $50 \%$ of $\mathrm{PM}_{2.5}$; Petit, 2014). Occasionally, some background levels of PM might not be accounted for in $\mathrm{PM}_{1}$ that are measured as $\mathrm{PM}_{2.5}$ (Petit, 2014). Moreover, comparisons made by Petit (2014) show a very similar statistical distribution for both $\mathrm{PM}_{1}$ at SIRTA and $\mathrm{PM}_{2.5}$ at the urban background stations in Paris suburbs mentioned in Fig. 4. For the future, it should be very interesting to have co-located $\mathrm{PM}_{1}$ and $\mathrm{PM}_{2.5}$ chemical composition measurements. The clear similarity of these measurements at four different locations of the Paris suburbs suggests that we may also expect a consistent evolution of pollution levels at the Créteil site (OASIS observatory), whose observations are also used later in this section for analyzing the evolution of the atmospheric ammonia concentrations during the event.

The time series of surface PM levels suggest the occurrence of two distinct pollution regimes within the period of 26-30 March. Indeed, while daily mean $\mathrm{PM}_{2.5}$ values during 26-27 March remain under the air quality $24 \mathrm{~h}$ guideline of WHO (World Health Organization, $\mathrm{PM}_{2.5}$ of $25 \mu \mathrm{g} \mathrm{m}^{-3}$, except for one station on 1 single day), this $\mathrm{PM}_{2.5}$ threshold is exceeded for all stations during 28-30 March. Hereafter, these two regimes are named period 1 or P1 (26-27 March) and period 2 or P2 (28-30 March). These two different atmospheric conditions are also pointed out by Petit et al. (2015) by analyzing this particular pollution episode using surface measurements at SIRTA. A statistical comparison of the similarity of surface PM measurements from different sites over the Paris region is shown in Table 1 (for periods 1 and 2). For the first period (26-27 March), the time series of hourly $\mathrm{PM}_{2.5}$ measurements performed at three different locations 

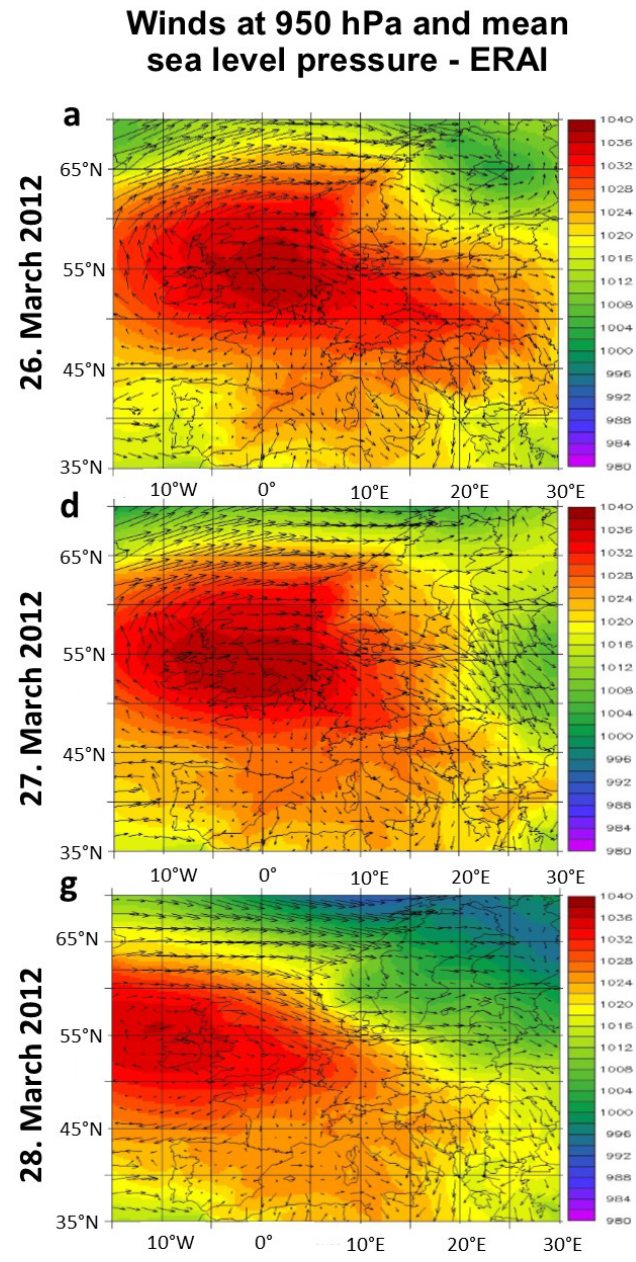

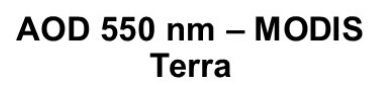

b
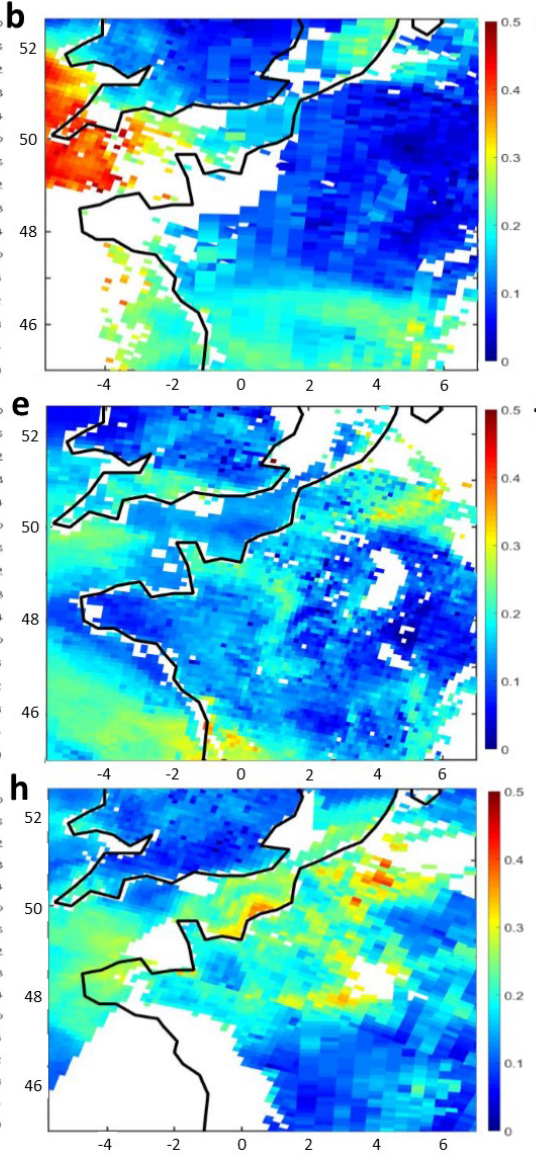

\section{Surface PM2.5 in $\mu \mathrm{g} / \mathrm{m}^{3}$ - CHIMERE}
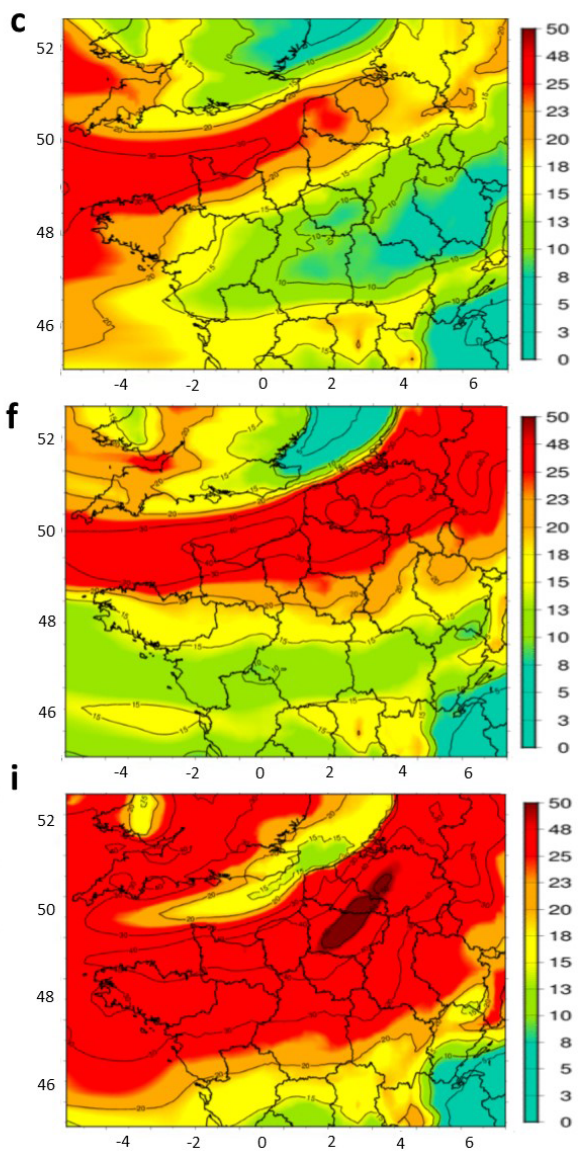

Figure 3. (a, d, g) Meteorological conditions characterized by $950 \mathrm{hPa}$ winds (arrows) and sea level pressure (shading) over Europe $\left(15^{\circ} \mathrm{W}\right.$ to $20^{\circ} \mathrm{E}$ and 40 to $65^{\circ} \mathrm{N}$ ) from ERAI reanalysis in 26-28 March 2012. Horizontal distribution of particles over northern France $\left(-5\right.$ to $7^{\circ} \mathrm{E}$ and 45 to $\left.52.5^{\circ} \mathrm{N}\right)$ in terms of $(\mathbf{b}, \mathbf{e}, \mathbf{h}) \mathrm{AOD}$ at $550 \mathrm{~nm}$ from MODIS aboard the Terra satellite and $(\mathbf{c}, \mathbf{f}, \mathbf{i}){\text { surface } \mathrm{PM}_{2.5}(\text { in } \mu \mathrm{g} \mathrm{m}}^{-3}$ ) from the CHIMERE model during the period 26-28 March 2012.

show a moderate correlation between each other $\left(R^{2}\right.$ of 0.63 to 0.67 ), suggesting a similar evolution but with some horizontal heterogeneity over the Paris region. During the second period (28-30 March), correlations between PM measurements are clearly higher $\left(R^{2}\right.$ of 0.86 to 0.91$)$ and therefore indicate a more horizontally homogeneous PM distribution over the Paris region. Levels of surface $\mathrm{PM}_{10}$ for the same stations and periods show similar behaviors (Table 1). This different behavior between $\mathrm{P} 1$ and $\mathrm{P} 2$ is likely linked to the origin of the pollution event, being rather local for P1 and dominant advection of air pollution from Benelux during P2, as remarked in the regional analysis of AOD, PM and wind regimes of Sect. 3.1. Additionally, we note that comparisons of $\mathrm{PM}_{2.5}$ from three stations to $\mathrm{PM}_{1}$ at SIRTA show moderate correlations during P1 as the other measurements but lower ones during P2 (although peaks and troughs are clearly coincident).

\subsection{Evolution of ammonia concentrations over the Paris region}

During the P1 and P2, ammonia concentrations over the Paris region are observed both at surface level (using in situ analyzer at SIRTA) and integrated over the total atmospheric column (using OASIS at Créteil, Fig. 5). Total atmospheric columns of $\mathrm{NH}_{3}$ show a very marked and clear diurnal evolution: lower column amounts of ammonia in the morning that rise almost monotonically during the day until reaching a maximum in the afternoon. Both on 26 and 27 March, stable ammonia concentrations around $2 \times$ $10^{16}$ molec. $\mathrm{cm}^{-2}$ remain until noon and then increase only in the afternoon. Early morning total columns of $\mathrm{NH}_{3}$ during 28 and 29 March are lower (respectively, $1.4 \times 10^{16}$ and $0.6 \times 10^{16}$ molec. $\mathrm{cm}^{-2}$ ) than for the previous days and show a steady enhancement from the early morning to the afternoon. The highest total column of ammonia is measured 
Table 1. Correlation of different available PM values of Vitry, Gennevilliers, Bobigny and SIRTA sites during 26-27 March (period 1) and 28-30 March (period 2). SE refers to standard error, and $R^{2}$ refers to the square of the correlation coefficient.

\begin{tabular}{lccccccccc}
\hline & \multicolumn{3}{c}{ 26-27 March (period 1) } & & \multicolumn{3}{c}{ 28-30 March (period 2) } \\
\cline { 2 - 3 } & Slope & SE & $R^{2}$ & & Slope & SE & $R^{2}$ \\
\hline $\mathrm{PM}_{2.5}$ Vitry vs. $\mathrm{PM}_{2.5}$ Gennevilliers & 0.84 & 0.09 & 0.67 & & 0.91 & 0.04 & 0.86 \\
$\mathrm{PM}_{2.5}$ Vitry vs. $\mathrm{PM}_{2.5}$ Bobigny & 0.89 & 0.10 & 0.63 & & 0.94 & 0.04 & 0.91 \\
\hline $\mathrm{PM}_{10}$ Vitry vs. $\mathrm{PM}_{10}$ Gennevilliers & 1.04 & 0.09 & 0.74 & & 1.04 & 0.05 & 0.84 \\
$\mathrm{PM}_{10}$ Vitry vs. $\mathrm{PM}_{10}$ Bobigny & 1.02 & 0.11 & 0.63 & & 0.93 & 0.07 & 0.73 \\
\hline $\mathrm{PM}_{1}$ SIRTA vs. $\mathrm{PM}_{2.5}$ Vitry & 0.57 & 0.06 & 0.67 & & 0.49 & 0.08 & 0.35 \\
$\mathrm{PM}_{1}$ SIRTA vs. $\mathrm{PM}_{2.5}$ Gennevilliers & 0.61 & 0.04 & 0.82 & & 0.44 & 0.09 & 0.26 \\
$\mathrm{PM}_{1}$ SIRTA vs. $\mathrm{PM}_{2.5}$ Bobigny & 0.57 & 0.04 & 0.84 & & 0.48 & 0.08 & 0.34 \\
\hline
\end{tabular}

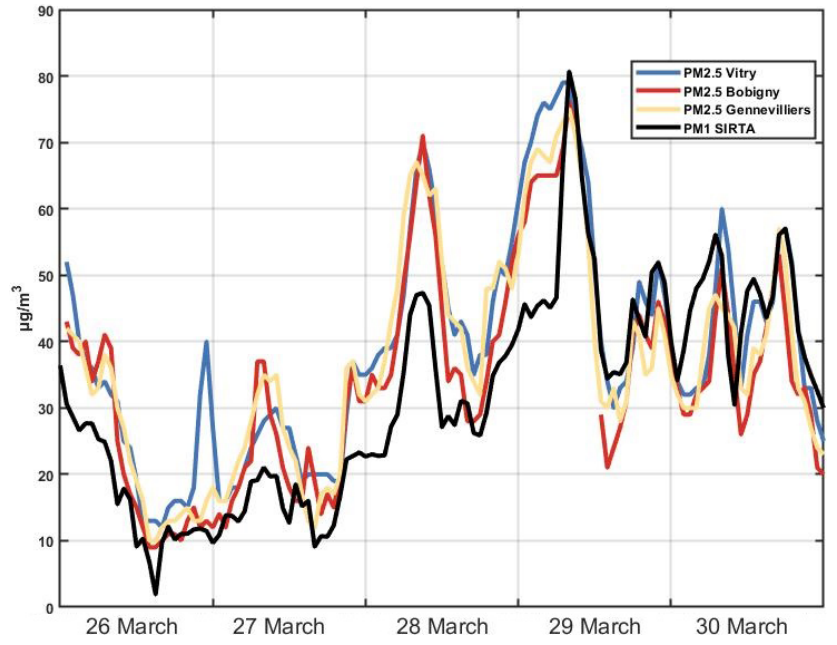

Figure 4. Particle matter concentrations measured at the surface at the stations of Vitry, Bobigny, Gennevilliers and SIRTA, respectively, southeast, northeast, northwest and southwest of Paris. Particle concentrations in terms of $\mathrm{PM}_{2.5}$ and $\mathrm{PM}_{1}$ are provided, respectively, at the three Airparif stations and at the last one in the period between 26-31 March 2012.

on 28 March $\left(4.6 \times 10^{16}\right.$ molec. $\left.\mathrm{cm}^{-2}\right)$. On 30 March, the diurnal evolution of $\mathrm{NH}_{3}$ total columns is more similar to the first 2 measurement days (26-27 March). Steady total columns around $1.5 \times 10^{16}$ molec. $\mathrm{cm}^{-2}$ during the first $1.5 \mathrm{~h}$ of the morning are followed by a decrease down to $0.85 \times 10^{16}$ molec. $\mathrm{cm}^{-2}$ around 11:00 UTC and afterwards an increase up to $2.5 \times 10^{16}$ molec. $\mathrm{cm}^{-2}$, which is lower than those observed during the 4 previous days. This clear enhancement of ammonia total atmospheric columns during the day measured by OASIS is found to be typical of springtime polluted periods as already analyzed by Tournade et al. (2020) but not shown here (e.g., in March 2014 and March 2016). For all these years, the $\mathrm{NH}_{3}$ maximum in the afternoon is above $2 \times 10^{16}$ molec. $\mathrm{cm}^{-2}$ (Tournadre et al., 2020).
Meanwhile, surface measurements at SIRTA show relatively high overall levels of ammonia: from 2 to $10 \mu \mathrm{g} \mathrm{m}^{-3}$, which is higher than Paris urban background levels of 1$3 \mu \mathrm{g} \mathrm{m}^{-3}$ shown by Petetin et al. (2016), but for the May 2010 to February 2011 period. On each of the days of the event (26-30 March), morning daily maxima (up to 6-9 $\mu \mathrm{g} \mathrm{m}^{-3}$ ) and smaller evening peaks (around $5 \mu \mathrm{g} \mathrm{m}^{-3}$, Fig. 5) are clearly depicted. Although both surface (Fig. 5b) and integrated total column (Fig. 5a) ammonia measurements show large concentrations, their daily evolution patterns are clearly different. While total column values increase steadily during the day until reaching a peak in the late afternoon, surface ammonia moderately fluctuates during the day. These differences may be associated with atmospheric processes or interactions with the surface that modify ammonia concentrations differently as a function of altitude. This may be the case for vertical dilution of atmospheric constituents within the atmospheric boundary layer or the vertical variability of gas-particle partitioning related to relative humidity, temperature and particle $\mathrm{pH}$. These aspects are investigated in detail in the following paragraphs.

Vertical variations of atmospheric ammonia concentrations may potentially be associated with temperature and relative humidity vertical profiles. As mentioned in Sect. 2.3, dry conditions lead to volatilization of ammonia from ammonium particles, whereas humidity levels beyond the deliquescence point favor the inverse process (Seinfeld and Pandis, 2016). During the pollution event during 26-30 March, temperature shows the usual steady decrease with altitude from the surface up to $2.5 \mathrm{~km}$ (see the median temperature profile measured by radiosoundings launched at Trappes during 26-30 March, Fig. 6a). Relative humidity varies greatly at the lowest few kilometers of the atmosphere, typically increasing with altitude within the mixing boundary layer (up to 1 to $1.5 \mathrm{~km}$ a.s.l., for the present case; see Fig. 6b). During 26-27 and 29 March, relative humidity increases from $25 \%$ at the surface up to $35 \%-40 \%$ around $900 \mathrm{~m}$ a.s.l. and drops above $1000 \mathrm{~m}$ a.s.l. down to $10 \%-20 \%$. On $28 \mathrm{March}$, relative humidity is roughly $15 \%$ higher than on the men- 

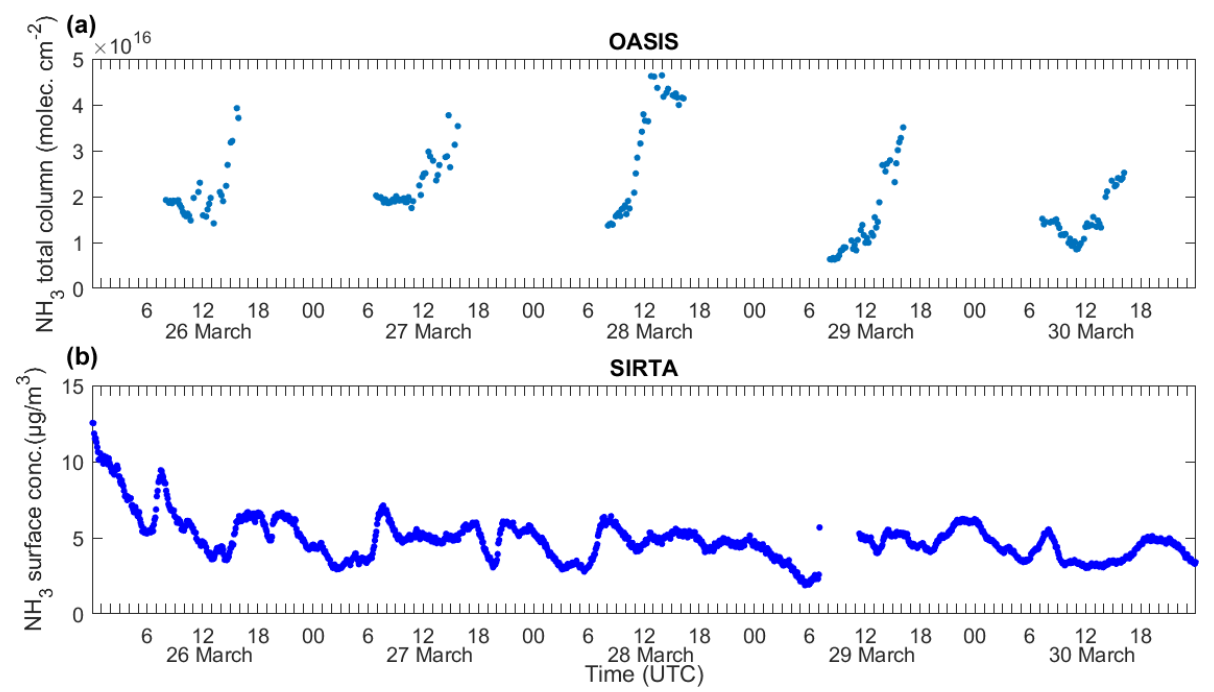

Figure 5. Observations of atmospheric ammoniac concentrations over the Paris region from 26 to 30 March 2012. The upper panel (a) displays total column retrievals at Créteil derived from OASIS observatory $\left(48.79^{\circ} \mathrm{N}, 2.44^{\circ} \mathrm{E}\right)$ measurements during the day $(\sim 07: 00$ and 16:00 UTC). The lower panel (b) displays continued ammonia surface concentration measurements from the AiRRmonia instrument near Palaiseau (SIRTA observatory; $48.71^{\circ} \mathrm{N}, 2.20^{\circ} \mathrm{E}$ ). This figure shows all available individual measurements from OASIS FTIR instrument and AiRRmonia in situ analyzer.

tioned days up to $800 \mathrm{~m}$ a.s.l., above which it decreases down to $48 \%$ and then rises up to $60 \%$ at $1600 \mathrm{~m}$ a.s.l., dropping down to $30 \%$ at $2500 \mathrm{~m}$ a.s.l. In all these cases, relative humidity up to $2500 \mathrm{~m}$ a.s.l. remains below the deliquescence point (DRH) as shown in Fig. 6b, thus favoring the formation of $\mathrm{NH}_{3}$ by volatilization of ammonium particles. This is also confirmed by relative humidity time series at different altitudes $(200,500$, and $1000 \mathrm{~m}$ a.s.l.), reconstructed from all radiosounding measurements over the entire event (launched from Trappes both at midday and midnight, Fig. 6c). This supports a hypothesis of an increase in ammonia amounts due to volatilization of ammonium nitrate at higher altitudes. Relative humidity always remains below the DRH (grey band), except for one single measurement at $1000 \mathrm{~m}$ on 30 March at noon. We also remark that during the whole period relative humidity does not vary much vertically below $1000 \mathrm{~m}$ (except on $30 \mathrm{March}$ ) and that the most humid conditions are found at midnights from 28 to 30 March. No contrasting conditions between midday and midnight are either found for the vertical shape of relative humidity. We do not clearly point out any particular link or concomitant temporal variation of relative humidity every $12 \mathrm{~h}$ at different altitudes (Fig. 6c) and ammonia measurements (Fig. 5).

An additional analysis was performed with the ISORROPIA II box model (Fountoukis and Nenes, 2007) to investigate the role of temperature and relative humidity in the partitioning of ammonium nitrate. The forward calculation used measurements of the SIRTA site for $\mathrm{NH}_{4}^{+}, \mathrm{NO}_{3}^{-}$and $\mathrm{NH}_{3}$ on 28 March 2012, representing the highest concentrations on the studied period, as well as the meteorological parameters. $\mathrm{HNO}_{3}$ concentrations were set constant from values in Petetin et al. (2016) for the same period of the year. As expected, results indicate that partitioning of ammonia into the particulate phase is favored with the decrease of temperature. This temperature decrease is correlated to an increase of relative humidity (while values remain below DRH). Therefore, in equilibrium conditions (e.g., in absence of ammonia and ammonium advection), ammonia likely decreases at higher altitudes. Nevertheless, it should be noted that $\mathrm{pH}$ and aerosol chemical composition also impact ammonium nitrate partitioning. $\mathrm{PM}_{1}$ was found to be neutralized during the period study (Fig. S1 in the Supplement); therefore, we expect a limited influence of ambient particle $\mathrm{pH}$. However, our full understanding is limited by the lack of $\mathrm{HNO}_{3}$ in situ and column measurements.

As a conclusion, the decrease in $T$ and the increase of $\mathrm{RH}$ within the boundary layer height of $1-1.5 \mathrm{~km}$ with respect to ground shift the equilibrium to the aerosol phase. This does not explain the observed daytime column $\mathrm{NH}_{3}$ maximum, which was not observed at the surface. This suggests that $T$ and RH may not be the only drivers regarding the vertical variability in $\mathrm{NH}_{3}$ concentrations. Other possible drivers are analyzed in the following sections.

\subsection{Link between ammonia and ammonium particles over the Paris region}

A joint analysis of the temporal evolution of ammonia and ammonium particles provides further evidence of the role of particle-gas conversion on the evolution of ammonia concentrations. As previously mentioned, volatilization leads to concomitant increases of ammonia concentrations and de- 

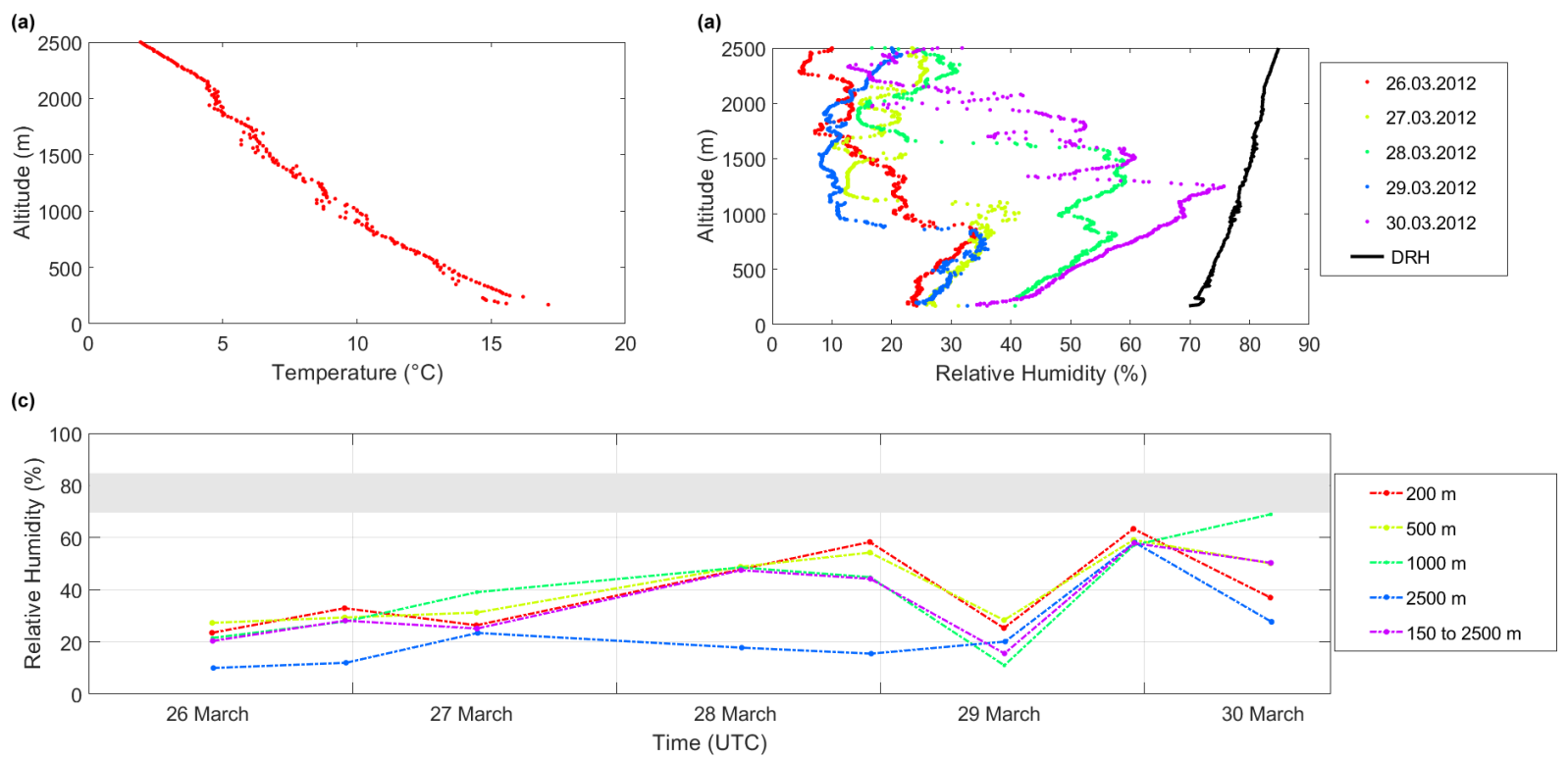

Figure 6. (a) Median temperature $\left({ }^{\circ} \mathrm{C}\right)$ over the period of interest in the vertical during midday. (b) Relative humidity $(\%)$ in the vertical (midday only) from Trappes station and DRH based on the median temperature from (a). (c) Relative humidity evolution at different heights (average over $\pm 25 \mathrm{~m}$ ) for all radiosoundings during 26-30 March, whereby the grey bar indicates the DRH lowest and highest values corresponding to 170 and $2500 \mathrm{~m}$ altitude. DRH refers to deliquescence relative humidity.

creases of $\mathrm{NH}_{4} \mathrm{NO}_{3}$ particles (the most abundant ammonium particles observed during this event; Petit et al., 2015). Complementary, the formation of ammonium nitrate particles may be accompanied by a relative reduction of the abundance of its precursors (if they are not in excess) and thus ammonia and $\mathrm{HNO}_{3}$. The following two subsections analyze these processes for periods 1 and 2 .

\subsubsection{Local pollution regime during 26-27 March 2012 (period 1)}

Figure 7 presents hourly median measurements of ammonia total column from OASIS and surface concentrations of ammonia, ammonium $\left(\mathrm{NH}_{4}^{+}\right)$, nitrate $\left(\mathrm{NO}_{3}^{-}\right)$and sulfate $\left(\mathrm{SO}_{4}^{2-}\right)$ radicals measured at the SIRTA site (respectively, in Fig. 7a, c and e, for P1, and Fig. 7b, d and f, for P2). During P1, hourly ammonia total columns measured by OASIS show a stable level around $2 \times 10^{16}$ molec. $\mathrm{cm}^{-2}$ until 10:00 UTC, after which a steady increase with larger variability is observed during all the afternoon until reaching a median maximum of $3.4 \times 10^{16}$ molec. $\mathrm{cm}^{-2}$ around 15:00 UTC (Fig. 7a). Surface ammonia concentrations strongly vary during the night and clearly increase in the morning hours with a relative maximum around 07:00 UTC up to $7 \mu \mathrm{g} \mathrm{m}^{-3}$, likely related to evaporation from morning dew (Petit et al., 2015; Wentworth et al., 2016) and it is followed by a steady decrease of about $35 \%$ down to $4.5 \mu \mathrm{g} \mathrm{m}^{-3}$ around 13:00 UTC. A second relative enhancement of surface $\mathrm{NH}_{3}$ is seen during the afternoon at 17:00 UTC until reaching $6 \mu \mathrm{g} \mathrm{m}^{-3}$, after which it fluctuates with concentra- tions around $5 \mu \mathrm{g} \mathrm{m}^{-3}$ until midnight (Fig. 7c). Hourly concentrations of $\mathrm{NH}_{4}^{+}$and $\mathrm{NO}_{3}^{-}$show a similar evolution during the day (Fig. 7c and e). They remain rather stable during the night and early morning hours until 06:00 UTC (around $\sim 5$ and $\sim 18 \mu \mathrm{g} \mathrm{m}^{-3}$ for, respectively, $\mathrm{NH}_{4}^{+}$and $\mathrm{NO}_{3}^{-}$), with a relative peak at 03:00 UTC. Afterwards, their concentrations show a small relative peak at 07:00 UTC, followed by a strong reduction of $75 \%$ during the day. Between noon and 19:00 UTC, a rather stable daily minimum is seen for both ammonium and nitrate concentrations (of, respectively, $\sim 1$ and $\sim 3 \mu \mathrm{g} \mathrm{m}^{-3}$ ). This is followed by a slight increase (up to 3 and $7 \mu \mathrm{g} \mathrm{m}^{-3}$, respectively). Meanwhile, sulfate amounts remain low during P1 (below $1.5 \mu \mathrm{g} \mathrm{m}^{-3}$, Fig. 7e).

From the early morning until the afternoon, the strong reduction of $75 \%$ for both ammonium and nitrate abundances at the surface, which is not clearly observed for surface ammonia (reducing by only $35 \%$ ), likely suggests the occurrence of volatilization of ammonium particles. Probably, particle volatilization may be observable locally in the Paris region as this first period (P1) is characterized by a rather local pollution regime with limited transport of pollutants from other regions. Sustained volatilization of ammonium particles would lead to a steady enhancement of ammonia concentrations, as is clearly observed during almost all of the daytime by OASIS in terms of $\mathrm{NH}_{3}$ total columns. Additionally, volatilization of applied mineral fertilizers in the surrounding crop areas may also contribute to the daytime increase of ammonia, as analyzed in detail during the same period (March/April 2012) over crop fields located west of Paris by Personne et al. (2015). 

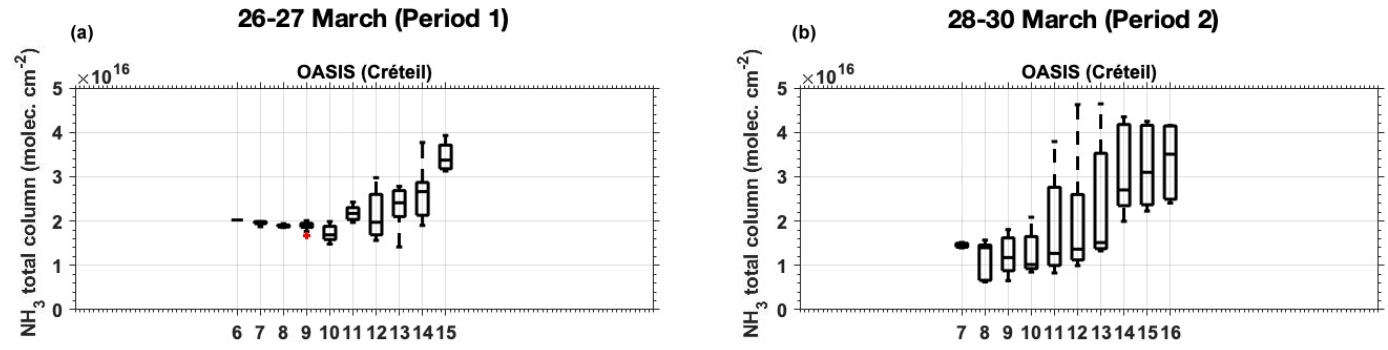

(c)

(d)
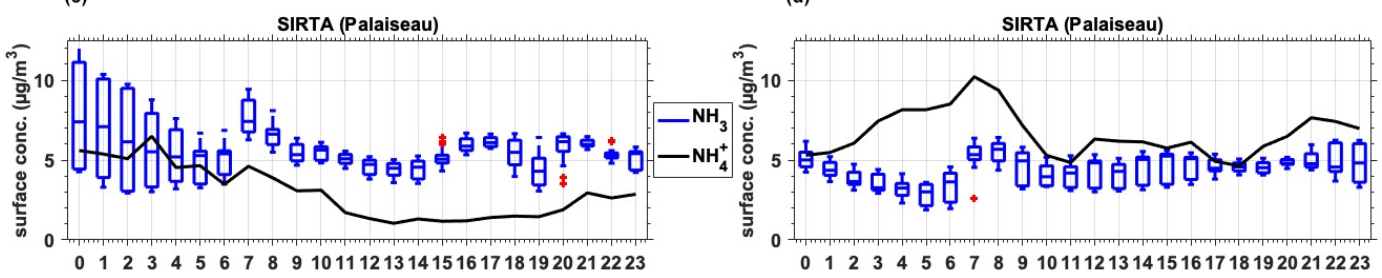

(e)

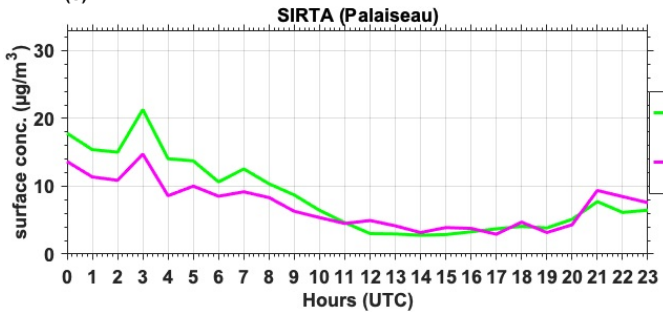

(f)

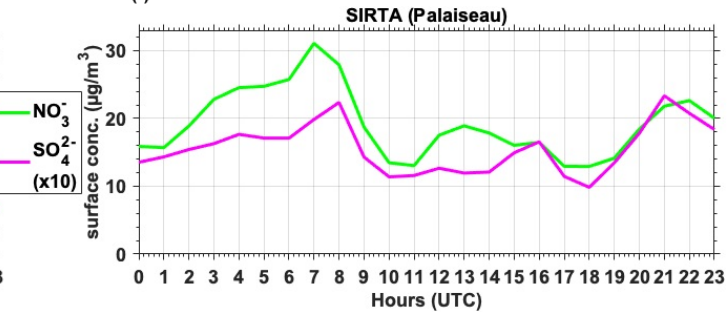

Figure 7. Average diurnal evolution of total column $\mathrm{NH}_{3}(\mathbf{a}, \mathbf{b})$, surface $\mathrm{NH}_{3}$ and $\mathrm{NH}_{4}^{+}\left(\mathbf{c}\right.$, d) hourly median surface measurements of $\mathrm{NO}_{3}^{-}$ and $\mathrm{SO}_{4}^{-2}(\mathbf{e}, \mathbf{f})$ for period 1 on the left side and period 2 on the right side. Hourly boxplots of $\mathrm{NH}_{3}$ total column retrieved from OASIS (a, b) and hourly boxplots of $\mathrm{NH}_{3}$ from surface measurements show within the boxplot the median as a line in the plot, 25th and 75th percentile as the lower and upper border of the box, and whiskers that extend to the most extreme data points, whereby outliers are separately marked with a "+".

Table 2. Meteorological variables at the surface and AOD during 26-27 March (period 1) and during 28-30 March (period 2), displayed by the median, minimum and maximum values for temperature, relative humidity, deliquescence relative humidity, and wind speed and direction - as well as AOD in its fine mode (FM) and coarse mode (CM).

\begin{tabular}{|c|c|c|c|c|c|c|}
\hline & \multicolumn{3}{|c|}{ period 1} & \multicolumn{3}{|c|}{ period 2} \\
\hline & Median & Minimum & Maximum & Median & Minimum & Maximum \\
\hline Temperature $\left({ }^{\circ} \mathrm{C}\right)$ & 16.2 & 10.8 & 21.8 & 14.8 & 10.5 & 21.0 \\
\hline Relative humidity (\%) & 41.8 & 19.0 & 66.0 & 54.8 & 26.5 & 77.0 \\
\hline Deliquescence relative humidity $(\%)$ & 70.9 & 65.1 & 76.7 & 72.1 & 65.6 & 77.2 \\
\hline Wind speed $\left(\mathrm{m} \mathrm{s}^{-1}\right)$ & 3.34 & 0.86 & 8.19 & 2.51 & 0.29 & 7.09 \\
\hline FM AOD $550 \mathrm{~nm}$ - Paris & 0.10 & 0.05 & 0.14 & 0.29 & 0.13 & 0.55 \\
\hline CM AOD $550 \mathrm{~nm}$ - Paris & 0.04 & 0.02 & 0.07 & 0.04 & 0.02 & 0.13 \\
\hline FM AOD $550 \mathrm{~nm}$ - SIRTA & 0.10 & 0.04 & 0.15 & 0.32 & 0.10 & 0.62 \\
\hline CM AOD $550 \mathrm{~nm}$ - SIRTA & 0.04 & 0.01 & 0.08 & 0.03 & 0.02 & 0.17 \\
\hline
\end{tabular}

The fact that the daytime enhancement of $\mathrm{NH}_{3}$ is not that clearly reflected by its variability at surface level (Fig. 7c) might be associated with an additional phenomenon that would reduce surface concentrations of gases and particles during daytime, such as vertical mixing within the atmospheric boundary layer (which is investigated in detail in Sect. 3.5). Volatilization of ammonium particles is also favored by rather dry conditions during the day, with sur- face relative humidity dropping down to $19 \%$ at about 12:00 UTC, while the deliquescence relative humidity point is $65 \%$ (Fig. 8c). Local meteorological conditions are also characterized by a gentle to fresh breeze, according to the Beaufort scale, with a dominant wind direction from the north (see Fig. 8e and g, Table 2) and surface temperatures ranging from 11 to $21^{\circ} \mathrm{C}$. 
(a)

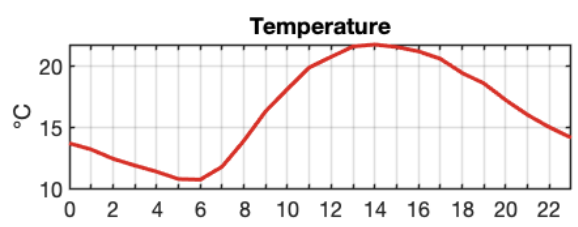

(c)

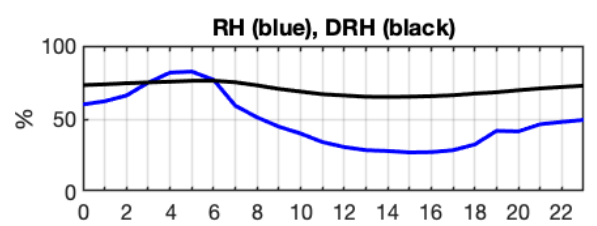

(e)

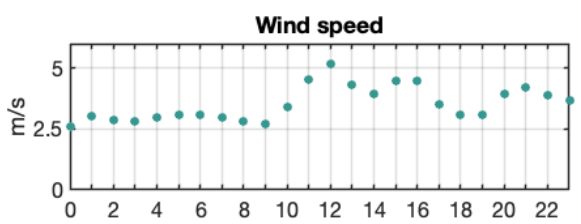

(g)

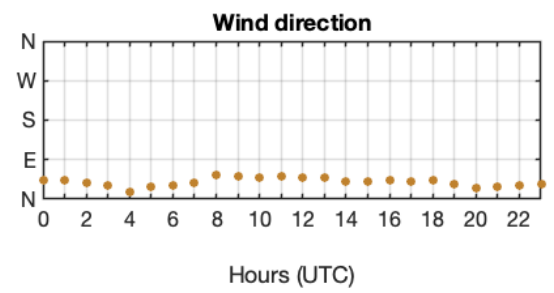

(b)

\section{8-30 March (Period 2)}

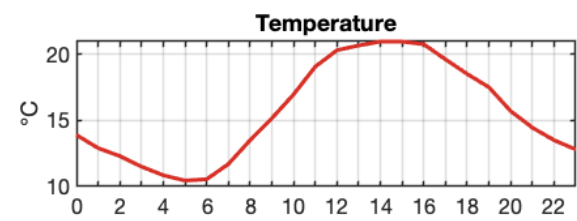

(d)

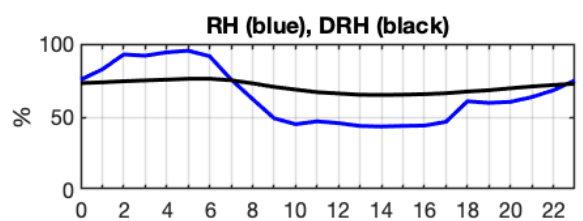

(f)

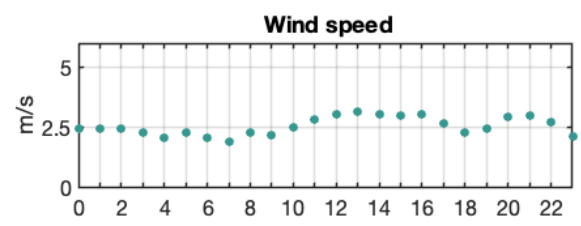

(h)

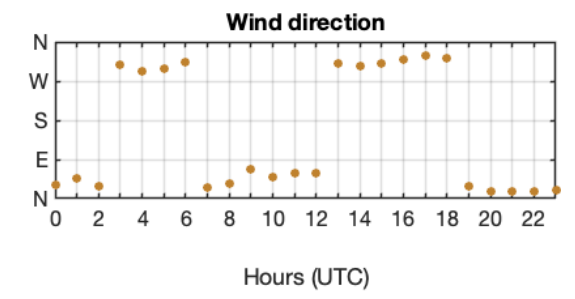

Figure 8. Hourly median surface temperature (in $\left.{ }^{\circ} \mathrm{C}\right)(\mathbf{a}, \mathbf{b})$, relative humidity (blue) and calculated deliquescence relative humidity (DRH; black) (in \%) (c, d), wind speed (in $\left.\mathrm{ms}^{-1}\right)(\mathbf{e}, \mathbf{f})$, and wind direction (in degrees) $(\mathbf{g}, \mathbf{h})$ are presented in $(\mathbf{a}, \mathbf{c}, \mathbf{e}, \mathbf{g})$ for period 1 and in $(\mathbf{b}, \mathbf{d}, \mathbf{f}, \mathbf{h})$ for period 2. Although temperature and relative humidity measurements originate from OASIS, wind speed and wind direction data originate from the SIRTA supersite.

\subsubsection{Pollution transported from the Benelux region and western Germany during 28-30 March 2012 (period 2)}

P2 is characterized by the arrival of polluted air masses to the Paris region, originating from the Benelux and western Germany region (as remarked in Sect. 3.1, Fig. 3c, f and i) by rather weak winds $\left(2.5 \mathrm{~m} \mathrm{~s}^{-1}\right.$, Fig. 8f) from the north and northeast (Fig. 8h). Locally, meteorological conditions favor particle formation during the night (maximum of $\mathrm{RH}$ of $95 \%$ above a DRH of $67 \%$, Fig. 8d) and volatilization during the day (minimum of RH of $27 \%$ well below the DRH of $66 \%)$. A clear and stronger afternoon enhancement of ammonia total columns is observed (Fig. 7b) as compared to the 2 previous days (P1, Fig. 7a). The median diurnal evolution patterns of ammonia columns during P2 depict an early decrease from $1.5 \times 10^{16}$ molec. $\mathrm{cm}^{-2}$ at 07:00 UTC down to $1 \times 10^{16}$ molec. $\mathrm{cm}^{-2}$ at 10:00 UTC. Then, they steadily rise for $6 \mathrm{~h}$ until reaching $3.5 \times 10^{16}$ molec. $\mathrm{cm}^{-2}$ at 16:00 UTC (Fig. 7b) with clearly more variability than during $\mathrm{P} 1$. Surface measurements of $\mathrm{NH}_{3}$ during the night show a steady decrease from $5 \mu \mathrm{g} \mathrm{m}^{-3}$ at midnight to $3 \mu \mathrm{g} \mathrm{m}^{-3}$ at 05:00 UTC, with smaller variability as compared to the same period of the day during $\mathrm{P} 1$. Surface $\mathrm{NH}_{3}$ concentrations increase during the morning until reaching a maximum of $5.7 \mu \mathrm{g} \mathrm{m}^{-3}$ at 08:00 UTC, followed by a reduction down to $4 \mu \mathrm{g} \mathrm{m}^{-3} 2 \mathrm{~h}$ after (10:00 UTC) and then a second relative maximum of smaller amplitude $\left(5 \mu \mathrm{g} \mathrm{m}^{-3}\right)$ in the afternoon (15:00 UTC, Fig. 7d). Ammonia emissions from the soil of surrounding crop areas may contribute to its enhancement during the morning (Personne et al., 2015). It is also worth noting that forests surrounding the $\mathrm{NH}_{3}$ surface measurement site at Palaiseau may act as local sinks of ammonia (as remarked by Behera et al., 2013; Hansen et al., 2015); this is not the case for total column retrievals performed at Créteil. 
When it comes to the particle components at surface level, all inorganics (ammonium, nitrate and sulfate) exhibit relatively large amounts and follow similar diurnal evolution patterns, which is probably associated with the arrival of air pollutants rich in nitrate (Fig. 7f; also remarked by Petit et al., 2015) from Benelux and western Germany (Fortems-Cheiney et al., 2016). The concentrations of these three particle components steadily increase during the night until reaching a maximum at 07:00 UTC (of 31, 10 and $2.3 \mu \mathrm{g} \mathrm{m}^{-3}$, respectively, for nitrate, ammonium, and sulfate), after which they decrease until 11:00 UTC. Between midnight and 05:00 UTC, the concomitant increase of the abundance of particle concentrations with a decrease in ammonia amounts might be associated with the gas-to-particle conversion process favored by high relative humidity and low temperatures (see Fig. 8b and d, Table 2) or eventually with the variability of particle concentrations being advected to the Paris region. In the afternoon, a second relative maximum of particle component concentrations at the surface is found around 12:00-13:00 UTC but with lower intensity (19, 6 and $1 \mu \mathrm{g} \mathrm{m}^{-3}$, respectively, for nitrate, ammonium and sulfate). An evening peak is also remarked around 22:00 UTC for the concentrations the three particle species (respectively, 23, 7 and $2 \mu \mathrm{g} \mathrm{m}^{-3}$ ). The daily evolution after 10:00 UTC of the particle components and ammonia is rather similar, without any particular anticorrelation which does not suggest a dominant formation or volatilization of particles.

\subsection{Vertical distribution of air pollutants over the Paris region}

In this subsection, we use vertical profiles of aerosol distributions measured by a backscatter lidar at SIRTA in order to analyze the link between air pollutant concentrations at the surface, their vertical profile and total column integrated amounts. Aerosol vertical distribution is used here as a proxy for air pollution, since no measurements of the diurnal evolution of the vertical profiles of gaseous pollutants such as ammonia or specific particle components such as ammonium or nitrate are available (only possible through very specific field deployments such as airborne in situ instrumentation or with a diode laser spectrometer aboard weather or tethered balloons with open cavity, for avoiding the problems of the sticky nature for ammonia). We depict the average diurnal evolution over $\mathrm{P} 1$ and $\mathrm{P} 2$, in terms of lidar measurements, sun-photometer-derived AODs and surface $\mathrm{PM}_{2.5}$ (see Fig. 9a-d). Moreover, we extract the time series of lidar attenuated backscatter at $150 \mathrm{~m}$ of altitude (the lowest level at which calibrated lidar measurements are available) for depicting the hourly evolution of near-surface air pollutant content (Fig. 9e and f, blue curves), and also we use attenuated backscatter integrated (indicated as IAB - integrated attenuated backscatter) over the altitude range from $150 \mathrm{~m}$ to $2.5 \mathrm{~km}$ for analyzing the corresponding variability of total column amounts (note that no aerosol layers are observed above $2.5 \mathrm{~km}$, Fig. 9e and f, red curves).

During P1 (27-28 March), baseline aerosol load conditions prevail over the Paris region, with an overall low AOD of both fine $(\sim 0.1)$ and coarse $(\sim 0.04)$ particle fractions (see fine mode AOD at SIRTA in Fig. 9a). This is also shown by lidar measurements, showing attenuated backscatter below $2.5 \mathrm{~km}$ of altitude (where particles are located), ranging from $2.5 \mathrm{Mm}^{-1} \mathrm{sr}^{-1}$ during the day up to a nighttime maximum of $4.3 \mathrm{Mm}^{-1} \mathrm{sr}^{-1}$ near the surface (Fig. 9c and e). According to the evolution of both attenuated backscatter at $150 \mathrm{~m}$ and surface $\mathrm{PM}_{2.5}$ concentrations, near-surface aerosol loads display a relative maximum from 07:00 to 10:00 UTC (thus during the morning peak of road traffic at the Paris megacity; Fig. 9a and e). This is followed by a progressive reduction of near-surface particle amounts from 10:00 until 13:00 UTC, as the atmospheric mixing boundary layer grows from a depth of $\sim 400 \mathrm{~m}$ at 10:00 UTC up to $\sim 1400 \mathrm{~m}$ at 13:00 UTC (shown as a dashed magenta line Fig. 9c). A late afternoon aerosol load increase from 16:00 until 19:00 UTC is also depicted by both integrated amounts (particularly backscatter) and near the surface (a small relative maximum), which corresponds to the time of the evening peak of road traffic. The attenuated backscatter data integrated from 0.15 to $2.5 \mathrm{~km}$ show two additional distinct peaks at 07:00 and 19:30 UTC of about 5.2 $\mathrm{Mm}^{-1} \mathrm{sr}^{-1}$, which are associated with enhancements of aerosol content from $700 \mathrm{~m}$ up to $1500 \mathrm{~m}$ of altitude (probably due to horizontal advection, Fig. 9c).

As previously remarked, P2 is characterized by a strong increase in particle load due to transboundary transport of pollution from Benelux and western Germany (Fig. 3c, f and i). This is reflected by large enhancements of the AOD, surface $\mathrm{PM}_{2.5}$ and lidar backscatter (Fig. 9b and f) as compared to P1. An increase of a factor of 3 of the fine mode fraction of the AOD (up to $\sim 0.29$ and $\sim 0.32$ in Paris and SIRTA, respectively) is observed, while the AOD coarse fraction remains stable $(\sim 0.04$ and $\sim 0.03$, respectively, in Paris and SIRTA, not shown in the figures). Integrated attenuated backscatter and surface $\mathrm{PM}_{2.5}$ during $\mathrm{P} 2$ are about a factor of $\sim 2$ greater than in the 2 previous days (P1). After a reduction from 07:00 to 11:00 UTC (also observed for ammonia total columns on 30 March, Fig. 5a), integrated attenuated backscatter shows a steady hourly enhancement from 12:00 until 19:00 UTC, when it displays a clear evening peak. This steady increase is also measured in terms of AOD but in this case during all daytime (from 07:00 to 17:00 UTC). This sustained increase during the daytime for vertically integrated amounts of particles is similar to that observed for the vertically integrated amount of ammonia measured by OASIS (Fig. 7b). Meanwhile, the near-surface evolution of particle content shown by both attenuated backscatter at $150 \mathrm{~m}$ of altitude and surface $\mathrm{PM}_{2.5}$ is clearly different from that of the total amount of particles (respectively, blue and red curves in Fig. $9 \mathrm{~b}$ and f). Near-surface aerosol amounts depict both the 
26-27 March (Period 1)

(a)

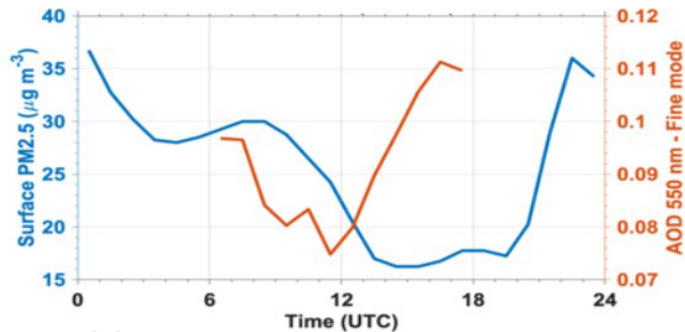

(c)

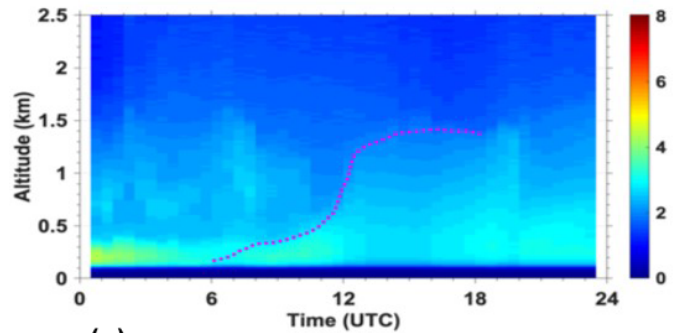

(e)

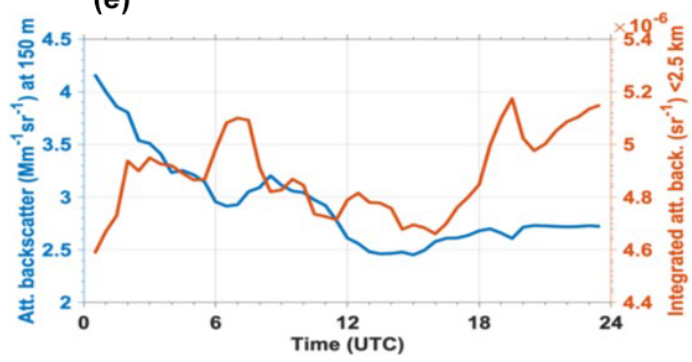

(b)

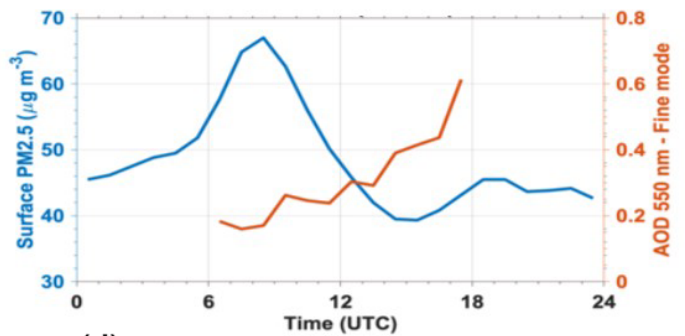

(d)

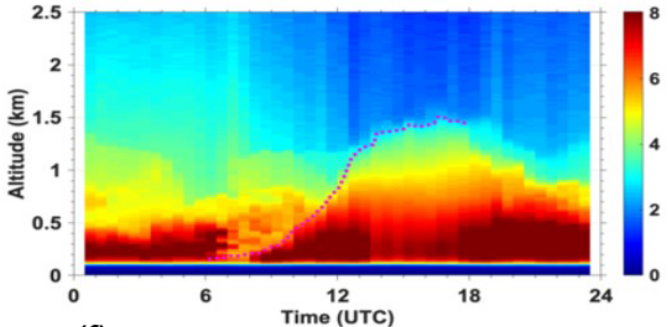

(f)

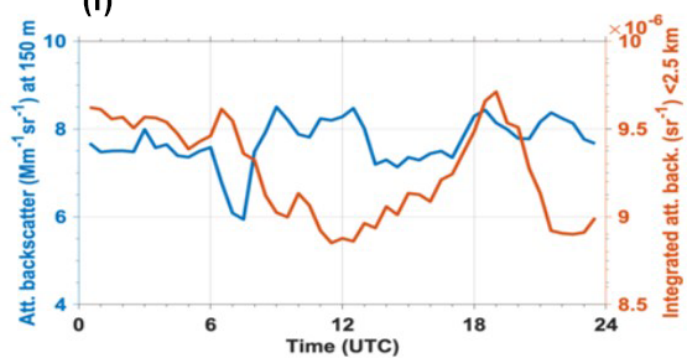

Figure 9. Median diurnal evolution of the AOD of the fine mode fraction of aerosols at $550 \mathrm{~nm}$ at SIRTA (red lines) and surface measurements of $\mathrm{PM}_{2.5}$ at Vitry (blue lines) during the periods (a) 26-27 March 2012 (P1) and (b) 28-30 March 2012 (P2). Median diurnal evolution of vertical profiles of attenuated backscatter measurements at $355 \mathrm{~nm}$ of a ground-based lidar at SIRTA for depicting the vertical distribution of aerosols during (c) P1 and (d) P2. Dashed magenta lines in (c) and (d) show the top of the mixing boundary layer manually tracked as the lowest discontinuity of the lidar profiles during daytime (06:00-18:00 UTC). Lidar-derived proxies of the diurnal evolution of particles over the total column (attenuated backscatter integrated between 0.15 and $2.5 \mathrm{~km}$ of altitude, in red) and near the surface (attenuated backscatter at $0.15 \mathrm{~km}$, in blue) for (e) P1 and (f) P2. For clarity, measurements in panels (a) and (b) are shown with hourly time resolution, whereas it is $30 \mathrm{~min}$ for panels $(\mathbf{c}-\mathbf{f})$.

morning (clearly marked for surface $\mathrm{PM}_{2.5}$ ) and evening relative maxima, that may be associated with road traffic. The reduction of lidar backscatter at $150 \mathrm{~m}$ at 07:30 UTC is likely associated with downward mixing of cleaner air (with fewer aerosols) from the residual layer (Fig. 9d at 07:30 UTC above $200 \mathrm{~m}$ ) above the mixing boundary layer. The afternoon minor reduction of particles coincides with a slight increase in wind speed, leading to vertical and horizontal mixing. An enhancement of particle amounts near the surface is only seen late in the afternoon (around 17:00-18:00 UTC). Surface ammonia concentrations show morning and evening peaks, with this last one only late in the afternoon. This confirms the consistency of the differences between near-surface and total amounts of particle concentrations with those between surface and total column ammonia.

The lidar profile time series reveals the link between surface and vertically integrated amounts of aerosols. It clearly depicts the typical diurnal cycle of the atmospheric boundary layer, with a growth of the mixing boundary layer from $\sim 150 \mathrm{~m}$ at 06:00 UTC to $\sim 1500 \mathrm{~m}$ at 14:00 UTC (see magenta dashed line in Fig. 9d, likely associated with turbulence generated by sunlight surface heating). Turbulenceassociated vertical dilution within the mixing boundary layer is most likely a major reason for the clear reduction of near-surface concentrations of particles between 06:00 and 14:00 UTC (and we expect the same behavior for surface $\mathrm{NH}_{3}$ also mixed within the boundary layer). This reduction is not remarked for vertically integrated amounts (AOD, attenuated backscatter or total column $\mathrm{NH}_{3}$ ) since a change in the vertical distribution does not affect the total atmospheric amount. We assume that relatively large vertically integrated amounts of particles between 00:00 and 07:00 UTC in P2 (compared to P1) are likely linked to particle formation. This is consistent with the relative humidity conditions (maximum 
(a)

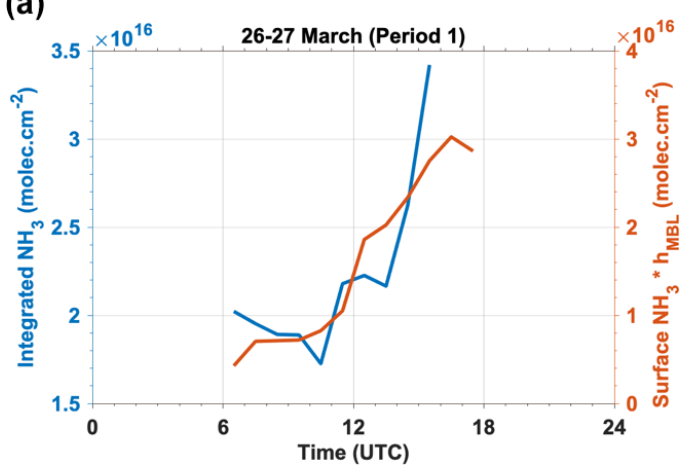

(b)

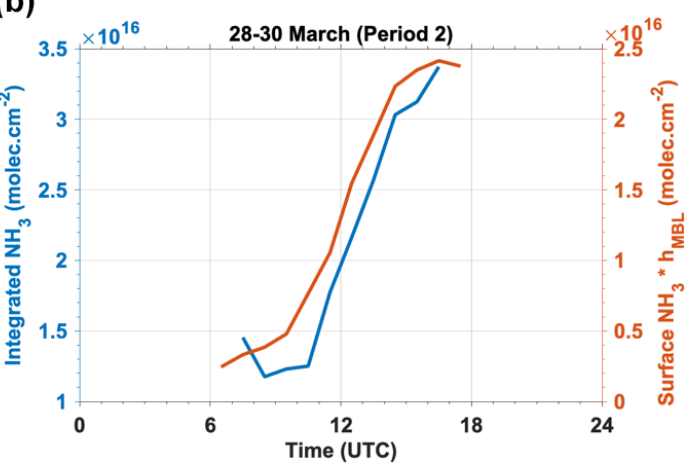

Figure 10. Diurnal evolution patterns of total column integrated ammonia concentrations retrieved by OASIS (blue lines) and surface concentrations measured in situ at SIRTA multiplied by the mixing boundary layer derived from lidar measurements (red lines) averaged over the periods (a) 26-27 March 2012 (P1) and (b) 28-30 March 2012 (P2). This last amount provides an estimate of the vertically integrated ammonia abundance over the atmospheric mixing boundary layer heights (those shown in Fig. 9c and d) in the case of a vertically homogeneous distribution of this gas.

of RH of $95 \%$ above DRH of $67 \%$, Fig. 8d) and also the low $\mathrm{NH}_{3}$ total columns measured by OASIS in the early morning (07:00 UTC) during P2 (see Figs. 7b and 5a, showing this last one early morning total columns of $\mathrm{NH}_{3}$ during 28-29 March smaller than the previous days).

Moreover, it is worth mentioning that although similarly affected by vertical mixing, the evolution patterns of integrated amounts of ammonia and particles are not necessarily linked to the same phenomena. Indeed, the sustained daytime or afternoon enhancement of particle total atmospheric amounts (AOD and integrated attenuated backscatter) during P2 is more likely associated with the advection of larger amounts of particle pollution during the afternoon or particle formation processes but not to volatilization (which is a sink of particles). However, the afternoon enhancement of ammonia may be reinforced by volatilization during the afternoon drier conditions (see Fig. 8d) and likely also horizontal advection of polluted air masses.

An additional analysis that highlights the major role of vertical mixing for comparing vertically integrated and surface measurements of ammonia is shown in Fig. 10. For both periods, we compare the daily evolution of total column of $\mathrm{NH}_{3}$ retrieved by OASIS with that of surface measurements of ammonia multiplied by the atmospheric mixing boundary layer derived from lidar measurements (magenta lines in Fig. 9c and d). This last one corresponds to the vertically integrated amount of ammonia over the mixing layer for the case of a vertically homogeneous distribution of this gas. We clearly remark a very similar diurnal evolution of these two quantities in relative terms, for both periods. This confirms the good consistency between these two independent measurements of ammonia (total column and surface data). Differences in absolute terms (between 0.5 to $1 \times 10^{6}$ molec. $\mathrm{cm}^{-2}$ ) likely come from the evolution of the vertical profile of ammonia, changes with respect to the vertically homogeneous distribution, and also the variability of ammonia abundance in the residual boundary layer and the free troposphere above the mixing layer.

Finally, local or regional emission sources could be a possible explanation for the observed $\mathrm{NH}_{3}$ enhancements during the afternoon. Agricultural $\mathrm{NH}_{3}$ emissions are weak over the greater Paris area, but they are strong over the adjacent Picardie and Ardenne-Champagne regions, located 30 to $150 \mathrm{~km}$ upwind of the Créteil measurement site for the northeasterly wind conditions during P1 and P2 (Fortems-Cheiney et al., 2020, Fig. 4c based on detailed emission modeling). The diurnal $\mathrm{NH}_{3}$ emission variation is strongly temperature dependent as shown, among others, by Hamaoui-Laguel et al. (2012) from simulations with a mechanistic emission model (Volt'Air; Génermont et al., 2018). Advection of these emissions to the Créteil site could be rapid enough to explain the observed afternoon $\mathrm{NH}_{3}$ column increase, given the surface wind speed of 3 to $5 \mathrm{~m} \mathrm{~s}^{-1}$ and probably faster winds at altitude.

\section{Conclusions}

We have carried out a comprehensive analysis of the diurnal evolution of ammonia amounts at the surface and over the total atmospheric column during a springtime pollution outbreak for the Paris megacity, considering different factors and variables that influence their variability at surface level and at altitude. Using remote sensing, meteorological and chemistry-transport models, we have described the regional atmospheric conditions over western Europe affecting air quality over the Paris region during late spring 2012. A clear picture of particulate pollution within the Paris region was drawn from in situ surface measurements of PM from the Paris region operational network. These results allowed us to distinctly identify two phases within the pollution outbreak in Paris: local formation of rather moderate pollution 
during 26-27 March 2012 (P1) and the arrival of relatively large amounts of transboundary pollution from Benelux and western Germany during 28-30 March 2012 (P2), leading to high surface $\mathrm{PM}_{2.5}$ concentrations (up to $80 \mu \mathrm{g} \mathrm{m}^{-3}$ ).

The daily evolution of ammonia in the Paris megacity was characterized by state-of-the-art measurements from the AiRRmonia surface in situ instrumentation and remote sensing of total atmospheric columns from the OASIS observatory. To the authors' knowledge, this is the first study analyzing the daily evolution of ammonia total columns with high temporal resolution (10 min in cloud-free conditions) over a megacity. Clearly different evolution patterns of ammonia concentrations at the surface and integrated over the atmospheric column were observed. Ammonia total columns during the late March 2012 pollution event depicted a clearly steady diurnal enhancement on each of the days of the event, during most of daytime ( $2 \mathrm{~d}$ ) or the afternoon ( $3 \mathrm{~d})$. On the other hand, surface ammonia measurements during this event principally revealed rather moderate fluctuations with significant morning-time peaks.

Despite a wide variety of factors influencing ammonia, our study distinctly identifies a crucial role of vertical mixing within the atmospheric boundary layer for explaining the difference between the evolution of ammonia at the surface and that integrated over the total column. Indeed, the growth of the mixing boundary layer from $150 \mathrm{~m}$ deep at 06:00 UTC up to $1500 \mathrm{~m}$ deep at 14:00 UTC entrains vertical dilution of atmospheric pollutants within the boundary layer and thus a relative reduction of air pollutant concentrations near the surface (but not over the total atmospheric column). By comparing surface (or near-surface) and total column amounts, we observe a similar behavior for both ammonia and particles. Both for P1 and P2, surface concentrations for these two pollutants mainly depict only morning and late afternoon peaks, while total columns show a steady enhancement particularly in the afternoon. Vertical dilution is then likely responsible for a prevailing reduction of surface concentrations until 14:00 UTC (explaining that they do not depict enhancements). Other processes such as surface and canopy uptake from surrounding ecosystems, depending on $\mathrm{pH}$, temperature, light and total nitrogen input, may also explain surface concentration reductions (Massad et al., 2010; Flechard et al., 2013; Personne et al., 2015). Afternoon enhancement for surface amounts is only seen later in the afternoon (16:0017:00 UTC). Moreover, the joint analysis of the evolution of ammonia, ammonium and nitrate highlighted the occurrence of volatilization of these last two to release ammonia in the atmosphere during the afternoon of $\mathrm{P} 1$. When it comes to $\mathrm{P} 2$, the evolution of total column amounts of ammonia and particles in the Paris region seems to be mainly driven by the arrival of polluted air masses originating from Benelux. Low relative humidity (clearly below the deliquescence point of ammonium nitrate) during the afternoons of the last period also suggests possible volatilization for enhancing the ammonia concentration (although this is not clearly seen as a major driver of measured nitrate or ammonium concentrations). However, the diurnal variation of $\mathrm{NH}_{3}$ emissions could be one of the factors leading to afternoon maxima, as emission sources are strong in the vicinity and upwind (under given conditions) of the Paris region. Nighttime ammonia and ammonium during P2 indicates gas-to-particle formation, which could also occur at higher altitudes (due to higher relative humidity, not shown), leading to distinct lower total column values of ammonia in the early morning (for $2 \mathrm{~d}$ ). This issue would be best addressed with chemistry-transport model simulations and dedicated in situ measurements (including nitric acid, particulate nitrate and ammonia) for the parametrization and validation of the model.

Our comprehensive study illustrates the benefit of using together total column and surface measurements of ammonia for understanding how vertical mixing within the atmospheric boundary layer influences the daily evolution of ammonia. This work also confirms the role of temperature and relative humidity for ammonia volatilization and particle formation.

For a particular geographical location, ground-based instruments in urban sites such as OASIS with high temporal resolution provide highly valuable information on the diurnal evolution of atmospheric species (especially gaseous pollutants). Ground-based remote sensing is also very valuable for validating satellite retrievals since both typically derive total column amounts of atmospheric species, which may significantly differ from their abundance at the surface.

The results of this study highlight the need for a better chemical characterization for comprehensive understanding of gas-particle partitioning over the column. A quantitative ammonia-ammonium equilibrium throughout the atmospheric column (as a function of altitude) should be considered from dedicated in situ measurements field campaigns. This may be addressed, for instance, by the development of spectroscopic instrumentation aboard standard weather or tethered balloons, capable of simultaneously measuring the vertical distribution of ammonia and particle components, in combination with chemistry-transport models, as already developed for greenhouse gases (such as $\mathrm{CO}_{2}, \mathrm{CH}_{4}$ and $\mathrm{H}_{2} \mathrm{O}$; see Joly et al., 2020).

Code availability. Details and access to PROFFIT code is provided by Frank Hase (frank.hase@ @it.edu) at the KIT, Karlsruhe, Germany. Further information is given within Hase et al. (2004).

Data availability. In the following, URLs are provided for data platforms, which were used within this study. Surface data from the SIRTA site are available via SIRTA/IPSL, http://sirta.ipsl.fr, last access 29 January 2019 (SIRTA, 2019). Maps from AirParif can be demanded via Interface de programmation applicative $\mid$ Airparif. OASIS data can be obtained by contacting Pascale Chelin (pascale.chelin@lisa.ipsl.fr) at the LISA, Créteil CEDEX, France. 
Data on AOD are accessible via the NASA Worldview website https://worldview.earthdata.nasa.gov/ (last access: 27 February 2019) (EOSDIS, 2019) and AErosol RObotic NETwork https://aeronet.gsfc.nasa.gov/cgi-bin/webtool_aod_v3 (last access: 9 June 2019) (NASA, 2019). Meteorological data are available from Pierre-Simon Laplace Mésocentre https://mesocentre.ipsl.fr (last access: 6 March 2019) (ESPRI, 2019) and https://www.ecmwf.int/ en/forecasts/datasets/reanalysis-datasets/era-interim (last access: 6 March 2019) (ECMWF, 2019). ERA-Interim reanalysis data are accessible via the ClimServ platform, https://climserv.ipsl. polytechnique.fr/ (last access: 24 April 2020) (ClimServ, 2020).

Supplement. The supplement related to this article is available online at: https://doi.org/10.5194/acp-21-12091-2021-supplement.

Author contributions. RDK is the main author of the paper; they wrote the text, made most of the figures and analyzed the data. JC, PC, JEP and MB contributed to the article writing, discussions and analysis of the figures. JC made one of the figures of the paper. JEP provided data and carried out the ISORROPIA II calculations. PC, MR and XL operated the OASIS observatory. BT and PC made an initial analysis of OASIS data. JCD provided observational data, and AR provided the ESMERALDA and CHIMERE outputs. FH and JO provided support for the analysis and the PROFFIT code for processing the OASIS dataset and deriving $\mathrm{NH}_{3}$ data.

Competing interests. The authors declare that they have no conflict of interest.

Disclaimer. Publisher's note: Copernicus Publications remains neutral with regard to jurisdictional claims in published maps and institutional affiliations.

Acknowledgements. The authors from LISA acknowledge support from CNES (Centre National des Etudes Spatiales) and the INSU/CNRS (Institut National des Sciences de l'Univers/Centre National de Recherche Scientifique) in the framework of the projects IASI-TOSCA (Terre Ocean Surface Continental Atmosphère) and LEFE-CHAT as well as the OSU-EFLUVE (Observatoire des Sciences de 1'Univers-Enveloppes Fluides de la Ville à l'Exobiologie) and the Université Paris-Est Créteil for the routine operation of the OASIS observatory. The research was also funded by DIM Qi2 (Paris region). A particular acknowledgement shall be given to the collaborator from KIT, Karlsruhe, Germany, for their continuous support and involvement. Work at IMK has been funded by the ATMO program of the Helmholtz Association of Germany Research Centres. The authors wish to thank Airparif and SIRTA, for in situ data and ground-based lidar measurements, and the NASA Goddard Space Flight Center, for providing the temperature and pressure profiles of the National Centers for Environmental Prediction (NCEP) (for the OASIS retrievals of $\mathrm{NH}_{3}$ ). Furthermore, our thanks extend to Airparif and their provision of the ESMERALDA output based on CHIMERE, used in this analysis, as well as the IPSL, providing the ERA-Interim re- analysis data that are accessible via the ClimServ platform (https: //climserv.ipsl.polytechnique.fr/, last access: 24 April 2020) platform by download. Thanks is extended to NASA Terra MODIS for providing data on their platform as well as the data.gouv.fr website, which provided shapefiles of the land use that were visualized with the QGIS software. Finally, the authors want to acknowledge and thank AERONET for the provision of the sun photometer data.

Financial support. This research has been supported by the Centre National des Etudes Spatiales (IASI-TOSCA (Terre Ocean Surface Continental Atmosphère)), the Institut national des sciences de l'Univers (LEFE-CHAT), the Helmholtz Association of Germany Research Centres (ATMO Program), and the Observatoire des Sciences de 1'Univers-Enveloppes Fluides de la Ville à l'Exobiologie, the Université Paris-Est Créteil and the DIM Qi2 (Paris region) (recurrent funding).

Review statement. This paper was edited by Rolf Müller and reviewed by two anonymous referees.

\section{References}

Behera, S. N. and Sharma, M.: Investigating the potential role of ammonia in ion chemistry offine particulatematter formation for an urban environment, Sci. Total Environ., 408, 3569-3575, https://doi.org/10.1016/j.scitotenv.2010.04.017, 2010.

Behera, S. N., Sharma, M., Aneja, V. P., and Balasubramanian, R.: Ammonia in the atmosphere: a review on emission sources, atmospheric chemistry and deposition on terrestrial bodies, Environ. Sci. Pollut. R., 20, 8029-8131, https://doi.org/10.1007/s11356-013-2051-9, 2013.

Chang, L., Palo, S., Hagan, M., Richter, J., Garcia, R., Riggin, D., and Fritts, D.: Structure of the migrating diurnal tide in the Whole Atmosphere Community Climate Model (WACCM), Adv. Space Res., 41, 1398-1407, https://doi.org/10.1016/j.asr.2007.03.035, 2008.

Chelin, P., Viatte, C., Ray, M., Eremenko, M., Cuesta, J., Hase, F., Orphal, J., and Flaud, J.-M.: The OASIS Observatory Using Ground-Based Solar Absorption Fourier-Transform Infrared Spectroscopy in the Suburbs of Paris (Créteil-France), Environmental, Ernergy and Climate Change I Environmental Chemistry of Pollutants and Wastes, Springer-Verlag, Berlin, Heidelberg, 21-52, https://doi.org/10.1007/698_2014_270, 2014.

Clerbaux, C., Boynard, A., Clarisse, L., George, M., Hadji-Lazaro, J., Herbin, H., Hurtmans, D., Pommier, M., Razavi, A., Turquety, S., Wespes, C., and Coheur, P.-F.: Monitoring of atmospheric composition using the thermal infrared IASI/MetOp sounder, Atmos. Chem. Phys., 9, 6041-6054, https://doi.org/10.5194/acp-96041-2009, 2009.

ClimServ: Présentation, available at: https://climserv.ipsl. polytechnique.fr/, last access: 24 April 2020.

Cortinovis, J., Moreto, F., Yahyaoui, A., Sauvage, A., and Letinois, L.: Élaboration d'un cadastre d'émissions interrégional pour la plate-forme de modélisation de prévisions cartographiques ESMERALDA, Pollution atmosphérique, Association pour la Prévention de la Pollution Atmosphérique, 
Paris, France, 189, 79-98, https://doi.org/10.4267/pollutionatmospherique.1503, 2006.

Cowen, K., Summer, A. L., Dindal, A., Riggs, K., Willenberg, Z., Hatfield, J., Pfieffer, R., and Scoggin, K.: Environmental Techology Verfication Report ETV Advanced Monitoring Systems Center Mechatronics Instruments BV AiRRmonia Ammonia Analyzer, Battelle in cooperation with US Department of Agriculture, under a cooperative agreement with US Environmental Protection Agency, Columbus, Ohio, 2004.

Dammers, E., Vigouroux, C., Palm, M., Mahieu, E., Warneke, T., Smale, D., Langerock, B., Franco, B., Van Damme, M., Schaap, M., Notholt, J., and Erisman, J. W.: Retrieval of ammonia from ground-based FTIR solar spectra, Atmos. Chem. Phys., 15, 12789-12803, https://doi.org/10.5194/acp-15-12789$2015,2015$.

Dammers, E., Shephard, M. W., Palm, M., Cady-Pereira, K., Capps, S., Lutsch, E., Strong, K., Hannigan, J. W., Ortega, I., Toon, G. C., Stremme, W., Grutter, M., Jones, N., Smale, D., Siemons, J., Hrpcek, K., Tremblay, D., Schaap, M., Notholt, J., and Erisman, J. W.: Validation of the CrIS fast physical $\mathrm{NH}_{3}$ retrieval with ground-based FTIR, Atmos. Meas. Tech., 10, 2645-2667, https://doi.org/10.5194/amt-10-2645-2017, 2017.

De Mazière, M., Thompson, A. M., Kurylo, M. J., Wild, J. D., Bernhard, G., Blumenstock, T., Braathen, G. O., Hannigan, J. W., Lambert, J.-C., Leblanc, T., McGee, T. J., Nedoluha, G., Petropavlovskikh, I., Seckmeyer, G., Simon, P. C., Steinbrecht, W., and Strahan, S. E.: The Network for the Detection of Atmospheric Composition Change (NDACC): history, status and perspectives, Atmos. Chem. Phys., 18, 4935-4964, https://doi.org/10.5194/acp-18-4935-2018, 2018.

Dudhia, J.: A nonhydrostatic version of the Penn StateNCAR mesoscale model: Validation tests and simulation of an Atlantic cyclone and cold front, Mon. Weather Rev., 121, 1493-1513, https://doi.org/10.1175/15200493(1993)121<1493:ANVOTP>2.0.CO;2, 1993.

ECMWF: ERA-Interim, available at: https://www.ecmwf.int/en/ forecasts/datasets/reanalysis-datasets/era-interim, last access: 6 March 2019.

Elster, M., El-Haddad, I., Maasikmets, M., Bozzetti, C., Wolf, R., Ciarelli, G., Slowik, J. G., Richter, R., Teinemaa, E., Hüglin, C., Baltensperger, U., and Prévôt, A. S. H.: High contributions of vehicular emissions to ammonia in three European cities derived from mobile measurements, Atmos. Environ. 175, 210220, https://doi.org/10.1016/j.atmosenv.2017.11.030, 2018.

EOSDIS: Welcome to Worldview!, available at: https://worldview. earthdata.nasa.gov/, last access: 27 February 2019.

ESPRI: Mésocentre de l'IPSL pour les sciences du Climat, available at: https://mesocentre.ipsl.fr, last access: 6 March 2019.

Flechard, C. R. Massad, R.-S., Loubet, B., Personne, E., Simpson, D., Bash, J. O., Cooter, E. J., Nemitz, E., and Sutton, M. A.: Advances in understanding, models and parameterizations of biosphere-atmosphere ammonia exchange, Biogeosciences, 10, 5183-5225, https://doi.org/10.5194/bg-10-5183-2013, 2013.

Fortems-Cheiney, A., Dufour, G., Hamaoui-Laguel, L., Foret, G., Siour, G., Van Damme, M., Meleux, F., Coheur, P.F., Clerbaux, L., Clarisse, L., Favez, O., Wallasch, M., and Beekmann, M.: Unaccounted variability in $\mathrm{NH}_{3}$ agricultural sources detected by IASI contributing to European spring haze episode, Geophys. Res. Lett., 43, 5475-5482, https://doi.org/10.1002/2016GL069361, 2016.

Fortems-Cheiney, A., Dufour, G., Dufossé, K., Couvidat, F., Gilliot, J.-M., Siour, G., Beekmann, M., Foret, G., Meleux, F., Clarisse, L., Coheur, P.-F., Van Damme, M., Clerbaux, C., and Génermont, S.: Do alternative inventories converge on the spatiotemporal representation of spring ammonia emissions in France?, Atmos. Chem. Phys., 20, 13481-13495, https://doi.org/10.5194/acp-2013481-2020, 2020.

Fountoukis, C. and Nenes, A.: ISORROPIA II: a computationally efficient thermodynamic equilibrium model for $\mathrm{K}^{+}$ $\mathrm{Ca}^{2+}-\mathrm{Mg}^{2+}-\mathrm{NH}_{4}^{+}-\mathrm{Na}^{+}-\mathrm{SO}_{4}^{2-}-\mathrm{NO}_{3}^{-}-\mathrm{Cl}^{-}-\mathrm{H}_{2} \mathrm{O}$ aerosols, Atmos. Chem. Phys., 7, 4639-4659, https://doi.org/10.5194/acp-74639-2007, 2007.

Génermont, S., Ramanantenasoa, M. M. J., Dufosse, K., Maury, O., Mignolet, C., and Gilliot, J.-M.: Data on spatio-temporal representation of mineral $\mathrm{N}$ fertilization and manure $\mathrm{N}$ application as well as ammonia volatilization in French regions for the crop year 2005/06, Data Brief, 21, 1119-1124, https://doi.org/10.1016/j.dib.2018.09.119, 2018.

Giles, D. M., Sinyuk, A., Sorokin, M. G., Schafer, J. S., Smirnov, A., Slutsker, I., Eck, T. F., Holben, B. N., Lewis, J. R., Campbell, J. R., Welton, E. J., Korkin, S. V., and Lyapustin, A. I.: Advancements in the Aerosol Robotic Network (AERONET) Version 3 database - automated near-real-time quality control algorithm with improved cloud screening for Sun photometer aerosol optical depth (AOD) measurements, Atmos. Meas. Tech., 12, 169209, https://doi.org/10.5194/amt-12-169-2019, 2019.

Guo, H., Otjes, R., Schlag, P., Kiendler-Scharr, A., Nenes, A., and Weber, R. J.: Effectiveness of ammonia reduction on control of fine particle nitrate, Atmos. Chem. Phys., 18, 12241-12256, https://doi.org/10.5194/acp-18-12241-2018, 2018.

Haeffelin, M., Barthès, L., Bock, O., Boitel, C., Bony, S., Bouniol, D., Chepfer, H., Chiriaco, M., Cuesta, J., Delanoë, J., Drobinski, P., Dufresne, J.-L., Flamant, C., Grall, M., Hodzic, A., Hourdin, F., Lapouge, F., Lemaître, Y., Mathieu, A., Morille, Y., Naud, C., Noël, V., O'Hirok, W., Pelon, J., Pietras, C., Protat, A., Romand, B., Scialom, G., and Vautard, R.: SIRTA, a ground-based atmospheric observatory for cloud and aerosol research, Ann. Geophys., 23, 253-275, https://doi.org/10.5194/angeo-23-253-2005, 2005.

Hamaoui-Laguel, L., Meleux, F., Beekmann, M., Bessagnet, B., Génermont, S., Cellier, P., and Létinois, L.: Improving ammonia emissions in air quality modelling for France, Atmos. Environ., 92, 584-595, https://doi.org/10.1016/j.atmosenv.2012.08.002, 2012.

Hansen, K., Pryor, S. C., Boegh, E., Hornsby, K. E., Jensen, B., and Sørensen, L. L.: Background concentrations and fluxes of atmospheric ammonia overa deciduous forest, Agr. Forest Meteorol., 214-215, 380-392, https://doi.org/10.1016/j.agrformet.2015.09.004, 2015.

Hase, F., Hannigan, J. W., Coffey, M. T., Goldman, A., Höpfner, M., Jones, N. B., Rinsland, C. P., and Wood, S. W.: Intercomparison of retrieval codes used for the analysis of high-resolution, ground-based FTIR measurements, J. Quant. Spectrosc. Ra., 87, 25-52, https://doi.org/10.1016/j.jqst.2003.12.008, 2004.

Holben, B. N., Tanré, D., Smirnov, A., Eck, T. F., Slutsker, I., Abuhassan, N., Newcomb, W. W., Schafer, J. S., Chatenet, B., Lavenu, F., Kaufman, Y. J., Vande Castle, J., Setzer, A., 
Markham, B., Clark, D., Frouin, R., Halthore, R., Karneli, A., O’Neill, N. T., Pietras, C., Pinker, R. T., Voss, K., and Zibordi, G.: An emerging ground-based aerosol climatology: Aerosol optical depth from AERONET, J. Geophys. Res.-Atmos., 106, 12067-12097, https://doi.org/10.1029/2001JD900014, 2001.

Joly, L., Coopmann, O., Guidard, V., Decarpenterie, T., Dumelié, N., Cousin, J., Burgalat, J., Chauvin, N., Albora, G., Maamary, R., Miftah El Khair, Z., Tzanos, D., Barrié, J., Moulin, É., Aressy, P., and Belleudy, A.: The development of the Atmospheric Measurements by Ultra-Light Spectrometer (AMULSE) greenhouse gas profiling system and application for satellite retrieval validation, Atmos. Meas. Tech., 13, 3099-3118, https://doi.org/10.5194/amt-13-3099-2020, 2020.

Krupa, S. V.: Effects of atmospheric ammonia $\left(\mathrm{NH}_{3}\right)$ on terrestrial vegetation: a review, Environ. Pollut., 124, 179-221, https://doi.org/10.1016/S0269-7491(02)00434-7, 2003.

Levy, R., and Hsu, C.: MODIS Atmosphere L2 Aerosol Product. NASA MODIS Adaptive Processing System, Goddard Space Flight Center, USA, https://doi.org/10.5067/MODIS/MOD04_L2.006 (Terra ,Aqua), 2015.

Massad, R. S., Nemitz, E., and Sutton, M. A.: Review and parameterisation of bi-directional ammonia exchange between vegetation and the atmosphere, Atmos. Chem. Phys., 10, 10359-10386, https://doi.org/10.5194/acp-10-10359-2010, 2010.

Meier, A., Toon, G. C., Rinsland, C. P., Goldman, A. and Hase, F.: A spectroscopic atlas of atmospheric microwindows in the middle infrared, IRF technical report 048, Swedish Institute of Space Physics, Kiruna, id e9e15084-c860-4d1b-8640-4ca2b616a714, 608 pp., 2004.

Molina, M. J. and Molina, L. T.: Megacities and Atmospheric Pollution, J. Air Waste Manage., 54:6, 644-680, https://doi.org/10.1080/10473289.2004.10470936, 2004.

NASA: AERONET Data Download Tool, available at: https://aeronet.gsfc.nasa.gov/cgi-bin/webtool_aod_v3, last access: 9 June 2019.

Nenes, A., Pilinis, C., and Pandis, S.: ISORROPIA: A new thermodynamic model for inorganic multicomponent atmospheric aerosols, Aquat. Geochem., 4, 123-152, https://doi.org/10.1023/A:1009604003981, 1998.

Ng, N. L., Herndon, S. C., Trimborn, A., Canagaratna, M. R., Croteau, P. L., Onasch, T. B., Sueper, D.,Worsnop, D. R., Zhang, Q., and Sun, Y. L.: An aerosol chemical speciation monitor (ACSM) for routine monitoring of the composition and mass concentrations of ambient aerosol, Aerosol Sci. Tech., 45, 780794, https://doi.org/10.1080/02786826.2011.560211, 2011.

Norman, M., Spirig, C., Wolff, V., Trebs, I., and Flechard, C., Wisthaler, A., Schnitzhofer, R., Hansel, A., and Neftel, A.: Intercomparison of ammonia measurement techniques at an intensively managed grassland site (Oensingen, Switzerland), Atmos. Chem. Phys., 9, 2635-2645, https://doi.org/10.5194/acp-9-26352009, 2009.

O’Neill, N. T., Eck, T. F., Smirnov, A., Holben, B. N., and Thulasiraman, S.: Spectral discrimination of coarse and fine mode optical depth, J. Geophys. Res.-Atmos., 108, 4559, https://doi.org/10.1029/2002JD002975, 2003.

Personne, E., Tardy, F., Génermont, S., Decuq, C., Gueudet, J.-C., Mascher, N., Durand, B., Masson, S., Lauransot, M., Fléchard, C., Burkhardt, J., and Loubet, B.: Investigating sources and sinks for ammonia exchanges between the atmosphere and a wheat canopy following slurry application with trailing hose, Agr. Forest Meteorol., 207, 11-23, https://doi.org/10.1016/j.agrformet.2015.03.002, 2015.

Petetin, H., Sciare, J., Bressi, M., Gros, V., Rosso, A., Sanchez, O., Sarda-Estève, R., Petit, J.-E., and Beekmann, M.: Assessing the ammonium nitrate formation regime in the Paris megacity and its representation in the CHIMERE model, Atmos. Chem. Phys., 16, 10419-10440, https://doi.org/10.5194/acp-16-104192016, 2016.

Petit, J.-E.: Compréhension des sources et des processus de formation de la pollution particulaire en région Ile-de-France, $\mathrm{PhD}$ manuscript of the University of Versailles Saint-Quentinen-Yvelines, France, 2014.

Petit, J.-E., Favez, O., Sciare, J., Crenn, V., Sarda-Estève, R., Bonnaire, N., Močnik, G., Dupont, J.-C., Haeffelin, M., and LeozGarziandia, E.: Two years of near real-time chemical composition of submicron aerosols in the region of Paris using an Aerosol Chemical Speciation Monitor (ACSM) and a multiwavelength Aethalometer, Atmos. Chem. Phys., 15, 2985-3005, https://doi.org/10.5194/acp-15-2985-2015, 2015.

Petit, J.-E., Amodeo, T., Meleux, F., Bessagnet, B., Menut, L., Grenier, D., Pellan, Y., Ockler, A., Rocq, B., Gros, V., Sciare, J., Favez, O.: Characterising an intense PM pollution episode in March 2015 in France from multi-site approach and near real time data: Climatology, variabilities, geographical origins and model evaluation, Atmos. Environ., 155, 68-84, https://doi.org/10.1016/j.atmosenv.2017.02.012, 2017.

Pinterits, M., Anys, M., Gager, M., Ullrich, B.: European Union emission inventory report 1990-2018 under the UNECE Convention on Long-range Transboundary Air Pollution (LRTAP), No. 05/2020, EEA - European Enviornment Agency, Denmark, 157 pp., https://doi.org/10.2800/233574, 2020.

Ramanantenasoa, M. M. J., Gilliot, J. M., Mignolet, C., Bedos, C., Mathias, E., Eglin, T., Makowski, D., and Génermont, S.: A new framework to estimate spatio-temporal ammonia emissions due to nitrogen fertilization in France, Sci. Total Environ., 645, 205219, https://doi.org/10.1016/j.scitotenv.2018.06.202, 2018.

Remer, L. A., Kaufman, Y. J., Tandré, D., Mattoo, S., Chu, D. A., Martins, J. V., Li, R.-R, Ichoku, C., Levy, R. C., Kleidman, R. G., Eck, T. F., Vermote, E., and Holben, B. N.: The MODIS Aerosol Algorithm, Products, and Validation, J. Atmos. Sci., 62, 947-973, https://doi.org/10.1175/JAS3385.1, 2005.

Sciare, J., d'Argouges, O., Sarda-Estève, R., Gaimoz, C., Dolgorouky, C., Bonnaire, N., Favez, O., Bonsang, B., and Gros, V.: Large contribution of water-insoluble secondary organic aerosolsin the region of Paris (France) during wintertime, J. Geophys. Res.-Atmos.,116, D22203, https://doi.org/10.1029/2011JD015756, 2011.

Seinfeld, J. H. and Pandis, S. N.: Atmospheric Chemistry and Physics: from Air Pollution to Climate Change, third ed., John Wiley \& Sons, New York, 1121 pp., 2016.

Serrano, H. C., Oliveira, M. A., Barros, C., Augusto, A. S., Pereira, M. J., Pinhp, P., and Branquinho, C.: Measuring and mapping the effectiveness of the European Air Quality Directive in reducing $\mathrm{N}$ and $\mathrm{S}$ deposition at the ecosystem level, Sci. Total Environ., 647, 1531-1538, https://doi.org/10.1016/j.scitotenv.2018.08.059, 2019. 
Shephard, M. W. and Cady-Pereira, K. E.: Cross-track Infrared Sounder (CrIS) satellite observations of tropospheric ammonia, Atmos. Meas. Tech., 8, 1323-1336, https://doi.org/10.5194/amt8-1323-2015, 2015.

Simmons, A., Uppala, S., Dee, D., and Kobayashi, S.: ERA-Interim: New ECMWF reanalysis products from 1989 onwards, ECMWF Newslett., 110, 25-35, https://doi.org/10.21957/pocnex23c6, 2007.

SIRTA: Home, available at: http://sirta.ipsl.fr, last access 29 January 2019.

Sommer, S. G., Schjoerring, J., and Denmead, O.: Ammonia Emission from Mineral Fertilizers and Fertilized Crops, Adv. Agron., 82, 557-622, https://doi.org/10.1016/S0065-2113(03)82008-4, 2004.

Sutton, A. D., Burrell, A. K., Dixon, D. A., Garner, E. B., Gordon, J. C., Nakagawa, T., Ott, K. C., Robinson, J. P., and Vasiliu, M.: Regeneration of ammonia borane spent fuel by direct reaction with hydrazine and liquid ammonia, Science, 331, 1426-1429, https://doi.org/10.1126/science.1199003, 2011.

Sutton, A. M., Reis, S., Riddick, S. N., Dragosits, U., Nemitz, E., Theobald, M. R., Tang, Y. S., Braban, C. F., Vieno, M., Dore, A. J., Mitchell, R. F., Wanless, S., Daunt, F., Fowler, D., Blackall, T. D., Milford, C., Flechard, C. R., Loubet, B., Massad, R., Cellier, P., Personne, E., Coheur, P. F., Clarisse, L., Van Damme, M., Ngadi, Y., Clerbaux, C., Skjøth, C. A., Geels, C., Hertel, O., Wichink Kruit, R. J., Pinder, R. W., Bash, J. O., Walker, J. T., Simpson, D, Horváth, L., Misselbrook, T. H., Bleeker, A., Dentener, F., and de Vries, W.: Towards a climate-dependent paradigm of ammonia emission and deposition, Philos. T. Roy. Soc. B, 368, 20130166, https://doi.org/10.1098/rstb.2013.0166, 2013.

Tournadre, B., Chelin, P., Ray, M., Cuesta, J., Kutzner, R. D., Landsheere, X., Fortems-Cheiney, A., Flaud, J.-M., Hase, F., Blumenstock, T., Orphal, J., Viatte, C., and Camy-Peyret, C.: Atmospheric ammonia $\left(\mathrm{NH}_{3}\right)$ over the Paris megacity: 9 years of total column observations from ground-based infrared remote sensing, Atmos. Meas. Tech., 13, 3923-3937, https://doi.org/10.5194/amt-13-3923-2020, 2020.

Van Damme, M., Whitburn, S., Clarisse, L., Clerbaux, C., Hurtmans, D., and Coheur, P.-F.: Version 2 of the IASI $\mathrm{NH}_{3}$ neural network retrieval algorithm: near-real-time and reanalysed datasets, Atmos. Meas. Tech., 10, 4905-4914, https://doi.org/10.5194/amt-10-4905-2017, 2017.

Viatte, C., Gaubert, B., Eremenko, M., Hase, F., Schneider, M., Blumenstock, T., Ray, M., Chelin, P., Flaud, J.-M., and Orphal, J.: Tropospheric and total ozone columns over Paris (France) measured using medium-resolution ground-based solar-absorption Fourier-transform infrared spectroscopy, Atmos. Meas. Tech., 4, 2323-2331, https://doi.org/10.5194/amt-4-2323-2011, 2011.
Viatte, C., Wang, T., Van Damme, M., Dammers, E., Meleux, F., Clarisse, L., Shephard, M. W., Whitburn, S., Coheur, P. F., Cady-Pereira, K. E., and Clerbaux, C.: Atmospheric ammonia variability and link with particulate matter formation: a case study over the Paris area, Atmos. Chem. Phys., 20, 577-596, https://doi.org/10.5194/acp-20-577-2020, 2020.

von Bobrutzki, K., Braban, C. F., Famulari, D., Jones, S. K., Blackall, T., Smith, T. E. L., Blom, M., Coe, H., Gallagher, M., Ghalaieny, M., McGillen, M. R., Percival, C. J., Whitehead, J. D., Ellis, R., Murphy, J., Mohacsi, A., Pogany, A., Junninen, H., Rantanen, S., Sutton, M. A., and Nemitz, E.: Field inter-comparison of eleven atmospheric ammonia measurement techniques, Atmos. Meas. Tech., 3, 91-112, https://doi.org/10.5194/amt-3-91-2010, 2010.

Weber, R. J., Guo, H., Russell, A. G., and Nenes, A.: High aerosol acidity despite declining atmospheric sulfate concentrations over the past 15 years, Nat. Geos., 9, 282-285, https://doi.org/10.1038/NGEO2665, 2016.

Wentworth, G. R., Murphy, J. G., Benedict, K. B., Bangs, E. J., and Collett Jr., J. L.: The role of dew as a night-time reservoir and morning source for atmospheric ammonia, Atmos. Chem. Phys., 16, 7435-7449, https://doi.org/10.5194/acp-167435-2016, 2016.

Whitehead, J. D., Twigg, M., Famulari, D., Nemitz, E., Sutton, M. A., Gallagher, M. W., and Fowler, D.: Evaluation of Laser Absorption Spectroscopic Techniques for Eddy Covariance Flux Measurements of Ammonia, Environ. Sci. Technol., 42, 20412046, https://doi.org/10.1021/es071596u, 2008.

Yokelson, R. J., Christian, T. J., Bertschi, I. T., and Hao, W. M.: Evaluation of adsorption effects on measurements of ammonia, acetic acid, and methanol, J. Geophys. Res.-Atmos., 108, 4649, https://doi.org/10.1029/2003JD003549, 2003.

Zhou, M., Langerock, B., Vigouroux, C., Sha, M. K., Ramonet, M., Delmotte, M., Mahieu, E., Bader, W., Hermans, C., Kumps, N., Metzger, J.-M., Duflot, V., Wang, Z., Palm, M., and De Mazière, M.: Atmospheric $\mathrm{CO}$ and $\mathrm{CH}_{4}$ time series and seasonal variations on Reunion Island from ground-based in situ and FTIR (NDACC and TCCON) measurements, Atmos. Chem. Phys., 18, 13881-13901, https://doi.org/10.5194/acp-18-138812018, 2018. 